\title{
NOJO, PRAZER E PERSISTÊNCIA: BEBER FERMENTADO ENTRE OS TUPINAMBÁ DE OLIVENÇA (BAHIA)
}

\author{
Susana de Matos Viegas \\ Instituto de Ciências Sociais da Universidade de Lisboa
}

\section{Resumo}

Este artigo analisa processos de transformação histórica na ingestão, preparação e interpelações suscitadas pelo consumo de uma bebida fermentada de mandioca (giroba) entre os Tupinambá de Olivença (costa sul da Bahia). Interligando esta etnografia com fontes históricas sobre o cauim entre os Tupinambá do século XVI e XVII e um enfoque de comparação americanista, o artigo mostra a importância de "comer fermentado" para uma perspectiva de longa-duração sobre socialidades Tupi.

\section{Pallavras-Chave}

Comida Fermentada $\bullet$ Tupinambá • Socialidades Ameríndias • Transformações Indígenas

\section{Abstract}

This article examines processes of historical transformation involved in the ingestion, preparation, and other issues involved in the consumption of a fermented beverage (giroba) made from manioc, among the Tupinambá of Olivença, on the southern coast of Bahia. In connecting ethnographic research with sixteenth and seventeenth-century sources on cauim (manioc beer) among the Tupinambá within a comparative Americanist focus, the article endeavors to show the importance of "eating" fermented brews for a longue-durée perspective on Tupi sociality.

\section{Keywords}

Fermented food • Tupinambá • Amerindian Socialities • Indigenous Transformations 
Este gentio é muito amigo do vinho, assim machos como fêmeas, o qual fazem de todos os seus legumes, até da farinha que comem; mas o seu vinho principal é de uma raiz a que chamam aipim, que se coze, e depois pisam-na e tornam-na a cozer (...); a esta água e sumo destas raízes lançam em grandes potes, que para isso têm, onde este vinho se coze, e está até que se faz azedo"

(Gabriel Soares de Sousa, "Que trata do modo de comer e do beber dos tupinambás”. In: Tratado descritivo do Brasil em 1587, p. 311).

Neste artigo exploro a importância cultural de se sentir prazer em comer certas comidas, particularmente uma bebida fermentada, na elaboração histórica da identidade entre os Tupinambá de Olivença ${ }^{1}$. Assumo que a cultura diz respeito antes que tudo à experiência vivida, entendendo-a como um complexo de sentimentos, emoções, símbolos e meios materiais que tornam essa experiência possível².

\footnotetext{
${ }^{1}$ Este artigo sustenta-se em trabalho de campo realizado no sul da Bahia no âmbito de três projetos de investigação. O primeiro e terceiro foram financiados pela Fundação da Ciência e Tecnologia do Ministério da Ciência de Portugal (ref. PCSH/C/ANT 42/96; POCTI/ANT/61198/ 2004). A segunda fonte de financiamento enquadra-se no trabalho de campo realizado sob o contrato que estabeleci com a Fundação Nacional do Índio e a UNESCO para a identificação da Terra Indígena Tupinambá de Olivença (ref. SA-12333/2004; 914BRA3018). Os resultados desta última investigação ainda em curso não são de forma alguma enunciados neste artigo, mas a pesquisa por ele propiciada teve um importante papel no amadurecimento intelectual das questões que aqui abordo. A elaboração deste artigo ganhou muito com as conferências que proferi em 2005 no Seminário de Investigação em Antropologia do Instituto de Ciências Sociais da Universidade de Lisboa em março de 2005, no CIASE, na Universidade de St Andrews (Escócia) em maio de 2005 e no Friday Seminars - Research Seminars in Anthropological Theory da London School of Economics (Reino Unido) em dezembro de 2005. Estou muito grata a todos os colegas presentes nesses seminários pelo debate propiciado e a João de Pina-Cabral/João Vasconcelos, Peter Gow e Charles Stafford pelo convite para participar, respectivamente, em cada um desses seminários. O meu agradecimento especial vai ainda para Tânia Stolze Lima cujos comentários à versão escrita deste último seminário foram de inestimável valor na solidificação do argumento. O texto e sustentação etnográfica que aqui apresento (bem como suas falhas) são de minha inteira responsabilidade. Deste conjunto de seminários resultou também uma versão diversa, mas de certa forma complementar sobre o mesmo tema da cerveja de mandioca e em inglês que está de momento a ser avaliada por referees numa revista de antropologia, sob o título "A long-term perspective on belonging: the pleasure of 'eating' manioc beer among the Tupinambá Indians of Olivença (Bahia, Brazil)".

${ }^{2}$ Ver TOREN, Christina. "Introduction: Mind, materiality and history” In: Mind, Materiality and History: Explorations in Fijian Ethnography. Londres: Routledge, 1999, pp. 1-21; SAHLINS, Marshall. "Pessimismo sentimental' e a experiência etnográfica: por que a cultura não é um "objeto" em vias de extinção (Parte I). Mana 3 (1), 1997, pp. 41-73; e PINACABRAL, João de. Between China and Europe: person, culture and emotion in Macao. Londres: Continuum, 2002.
} 
Os Tupinambá de Olivença viveram vários projetos verdadeiramente modernos. Fizeram parte de um aldeamento jesuíta, sendo os habitantes da aldeia de Nossa Senhora da Escada, edificada em 1680 e localizada a cerca de $15 \mathrm{~km}$ a sul da cidade de Ilhéus, no sul da Bahia ${ }^{3}$. Uma das mais consistentes orientações civilizacionais dos jesuítas nesse período foi a de impedir que se perpetuassem os "costumes" dos povos Tupi que mais abertamente eram contrários à moralidade da pessoa cristã, entre os quais, para o que aqui importa relevar, estavam as festividades e rituais demonizados pela ingestão exacerbada de uma bebida fermentada conhecida por cauym. Como mostrou recentemente João Azevedo Fernandes, o que foi considerado uma ameaça à moralidade cristã pelos jesuítas não foi apenas a embriaguez, mas especificamente a "embriaguez cerimonial dos índios", isto é, as cauinagens ${ }^{4}$.

Neste artigo sigo os sentidos de longa duração e a relação dos Tupinambá de Olivença com o passado através de interpretações e observações sobre a ingestão de uma bebida que os Tupinambá designam de giroba, aproximada às imensas variedades que conhecemos para a Amazônia sob as designações de cauym, chicha, cachiri, Ouicou, caissuma ${ }^{5}$. Essa análise leva-nos a ultrapassar

\footnotetext{
${ }^{3}$ Ver LEITE, Serafim, S.I. "Ilhéus". História da Companhia de Jesus no Brasil: Da Baía ao nordeste: estabelecimentos e assuntos locais. Tomo V. Lisboa/Rio de Janeiro: Livraria Portugália/Civilização Brasileira, 1945, p. 222; e LISBOA, Balthasar da Silva, "Officio do Juiz Conservador das Mattas da comarca dos Ilhéos, Balthasar da Silva Lisboa, para o Visconde da Anadia, no qual se refere aos seus serviços e à remessa da seguinte memória sobre a comarca dos Ilhéos. Villa de Valença, 27 de Junho de 1802 (Documento $\mathrm{n}^{\circ} 24.002$ e n $^{\circ}$ 24.003, Annexa ao $\mathrm{n}^{\circ}$ 24.002). In: ALMEIDA, Eduardo Castro. Inventário dos Documentos relativos ao Brasil existentes no Archivo de Marinha e Ultramar de Lisboa. Vol IV "Bahia: 1798-1800". Rio de Janeiro: Oficinas da Biblioteca Nacional, 1916, p. 10. No relatório do Ouvidor da Bahia que em 1758 "elevou" o aldeamento jesuíta a "Vila de índios de Olivença" Luiz Freire de Veras explicita que o primeiro livro de assentos de batismos encontrado na igreja da aldeia de Nossa Senhora da Escada data de 20 de Novembro de 1682 e foi iniciado pelo padre Teodósio de Moraes (Cf. DIAS, Marcelo Henrique. "A Inserção Econômica dos Aldeamentos Jesuíticos na Capitania de Ilhéus”. In: CARRARA, Ângelo Alves e DIAS, Marcelo Henrique (orgs.). Um Lugar na História: a Capitania e Comarca de Ilhéus antes do cacau. Ilhéus: Editus, no prelo, p. 16). O relatório tem por referência Respostas aos quesitos retro respectivos à Aldeia de N. S. da Escada, hoje V. de Nova Olivença, Bahia e mais: N. S. das Candeias; Santo André e São Miguel de Serinhaem. 1768. 33 f., Biblioteca Nacional do Rio de Janeiro, ms 512 (28) (cf. DIAS, "A Inserção Econômica”, op.cit.).

${ }^{4}$ Ver FERNANDES, João Azevedo. Selvagens Bebedeiras: álcool, embriaguez e contatos culturais no Brasil Colonial. Tese de Doutoramento do PPGH, Universidade Federal Fluminense, Niterói, 2004, pp. 312, 315, 330.

${ }^{5}$ Ver ERIKSON, Philippe. "L'art de couler des jours heureux: les boissons traditionelles en Amazonie." In: Brésil Indien: les arts des Améridiens du Brésil. Paris: Galeries Nationales du Grand Palais, 2005, p. 244.
} 
os conceitos de "emergência" ou "ressurgimento" para descrever os processos de identidade de índios que, como os Tupinambá de Olivença, viveram histórias complexas e longas de sujeição a processos civilizatórios, propondo uma visão mais etnográfica da história ${ }^{6}$. Contextualizando esta etnografia nos debates americanistas sobre a pessoa, o corpo e a alimentação e fazendo articulações com as fontes dos cronistas do século XVI, proponho que pensemos em quatro "epistemologias da história dos Tupinambá de Olivença”.

Chamo nojo a uma dessas epistemologias, por se associar com a idéia de repelir, cortar, rejeitar partes do passado, aqui ligado etnograficamente e expresso literalmente num sentimento de nojo.

Chamo persistência a outra, por lidarmos com formas de dar continuidade a práticas e sentidos (culturais) do passado que constituem linhas de repetição ou fixidez, mas também indicações ontogênicas sobre a pessoa Tupinambá.

Sem nostalgia define processos de rememoração de práticas associadas à preparação da bebida que se deixaram de fazer, sem que com isso tenham passado a ser objeto de recuperação cultural, como acontece nos processos de re-tradicionalismo.

Prazer é o sentido central da história como experiência vivida. Estamos a falar do prazer como habitus, isto é, como disposição existente no corpo. De certa forma é ele que explica a persistência de práticas como a ingestão de uma bebida fermentada considerada azeda para o paladar regional da Bahia. É também através dele que mais diretamente ligamos a socialidade dos Tupinambá de Olivença com o que tem sido dito sobre a centralidade do corpo como locus de socialidade ameríndia ${ }^{7}$. Nesta última linha analítica, aquilo que se ingere torna-se não apenas num alimento no sentido nutritivo, mas também um parâmetro de sensações constitutivas da sociedade.

\footnotetext{
${ }^{6}$ Ver ARRUTI, José Maurício Andion. "A Emergência dos Remanescentes: notas para o diálogo entre indígenas e quilombolas”. Mana 3(2) 1997, pp. 7-38 e OLIVEIRA, João Pacheco. "Uma Etnologia dos 'Índios Misturados'? Situação colonial, territorialização e fluxos culturais". In: OLIVEIRA, João Pacheco, (org.). A Viagem da Volta: Etnicidade, política e reelaboração cultural no Nordeste indígena. Rio de Janeiro: Contra Capa, 1999, pp. 11-40.

${ }^{7}$ Ver por exemplo SEEGER, Anthony, VIVEIROS DE CASTRO, Eduardo, e DA MATTA, Roberto. "A Construção da Pessoa nas Sociedades Indígenas Brasileiras". Boletim do Museu Nacional 32, 1979, pp. 2-19; VIVEIROS DE CASTRO, Eduardo. “Apresentação" In: VILAÇA, Aparecida. Comendo como gente. Rio de Janeiro: ANPOCS, UFRJ Editora, 1992, pp. XI-XXIII; e VILAÇA, Aparecida. "Chronically unstable bodies: reflections on Amazonian corporalities". Journal of the Anthropological Royal Institute (n.s.) 11, 2005. pp. 445-464.
} 
Argumento, por fim, que a força histórica deste tipo de alimento se associa de forma muito estreita ao fato de estarmos a falar em primeiro lugar de uma bebida preparada com mandioca e em segundo lugar a um fermentado preparado através de um triplo ou quádruplo cozimento.

\section{Ainda estão aí?}

O meu conhecimento dos Tupinambá de Olivença resulta de trabalho de campo com observação participante que realizei no período continuado de um ano entre Agosto de 1997 e Agosto de 1998, quando convivi mais intensamente com a população indígena que vive na localidade de Sapucaeira. Nesta localidade, o cultivo de mandioca e a preparação de múltiplos derivados culinários da mandioca é a atividade de auto-subsistência mais comum. Nesse período os Tupinambá de Olivença chamavam-se a si-próprios "índios ou caboclos", tendo sabido resignificar positivamente este último termo. A sua identificação como Tupinambá de Olivença formalizou-se em 2000, quando enviaram um pedido formal para a Fundação Nacional do Índio reivindicando o seu reconhecimento indígena. Imediatamente passaram a ser classificados numa das mais recentes e problemáticas categorias do indigenismo: "índios emergentes". Num rumo oposto ao que a caracterização mais clássica da história indígena lhes guardava - a história fria de Lévi-Strauss - a categoria "índios emergentes" tem promovido um pernicioso naturalismo que remete qualquer caso de reivindicação de identidade indígena no nordeste para o re-tradicionalismo.

Na etnografia que resultou deste primeiro período de trabalho de campo abordei a importância de "dar de comer" como uma dimensão central do que significa ser parente, ao mesmo tempo que prestei atenção à dimensão do prazer em ingerir certos alimentos como uma dimensão central da socialidade ${ }^{8}$. Foi, no

\footnotetext{
${ }^{8}$ VIEGAS, Susana de Matos. "Eating with your favourite mother: time and sociality in a South Amerindian community (South of Bahia/Brazil)". Journal of the Royal Anthropological Institute (including Man). Vol 9 (1), 2003, pp. 21-37, e VIEGAS, Susana de Matos. Socialidades Tupi: identidade e experiência vivida entre índios-caboclos (Bahia, Brasil). Tese de doutoramento. Universidade de Coimbra, Portugal, 2003. Sobre este mesmo assunto da alimentação e comensalidade nas socialidades ameríndias veja-se BELAÚNDE, Luisa Elvira. "The Convivial Self and the Fear of Anger amongst the Airo-Pai of Amazonian Peru". In: PASSES, Alan e OVERING, Joanna (orgs.). The Anthropology of Love and Anger: the esthetics of conviviality in Native Amazonia. Londres e Nova York: Routledge, 2000, p. 209; BELAÚNDE, Luisa Elvira. Viviendo Bién: género y fertilidad entre los Airo-Pai de la
} 
entanto, numa segunda etapa/período do meu conhecimento antropológico dos Tupinambá de Olivença iniciada em 2003, no âmbito de um contrato UNESCO/ FUNAI para fazer o estudo antropológico de identificação da Terra Indígena Tupinambá de Olivença, que os dados sobre a giroba ganharam maior relevância empírica. Ao percorrer as diferentes áreas do território acabei por integrar a questão da giroba nas perguntas que com sistematicidade fui repetindo nos "inquéritos etnográficos" a um conjunto muito vasto de casas e "unidades compósitas de residência" ou lugares ${ }^{9}$. Esta última experiência de terreno decorreu em apenas dois meses repartidos entre agosto de 2003 e fevereiro-março de 2004, inscrevendo uma forma de levantamento de dados empíricos que em antropologia aproximaríamos mais ao tipo "expedição" (pela rapidez e a cobertura extensiva exigida), do que ao trabalho de campo.

Amazonía Peruana. Lima: Centro Amazónico de Antropología y Aplicación Práctica, 2001, p. 182; GOW, Peter. Of Mixed Blood: Kinship and History in Peruvian Amazonia. Oxford: Clarendon Press, 1991; GOLDMAN, Irving. Cubeo Hehénewa Religious Thought: metaphysics of a Northwestern Amazonian People. Nova York: Columbia University Press, 2004, p. 142; McCALLUM, Cecilia. "Alteridade e sociabilidade Kaxinauá: perspectivas de uma antropologia da vida diária" Revista Brasileira de Ciências Sociais 13 (38), 1998, pp. 127-136; FAUSTO, Carlos. "Banquete de Gente: comensalidade e canibalismo na Amazônia" Mana 8 (2), 2002, p. 15; SISKIN, Janet. To hunt in the morning. Oxford: Oxford University Press, 1973, p. 9, VILAÇA, Aparecida. "Fazendo corpos: reflexões sobre morte e canibalismo entre os Wari' à luz do perspectivismo" Revista de Antropologia 41 (1), 1998. pp. 9-67; VILAÇA, "Chronically unstable bodies", op.cit., p. 446; VIVEIROS DE CASTRO, Eduardo. "O conceito de sociedade em antropologia". In: A inconstância da alma selvagem e outros ensaios de antropologia. São Paulo: Cosac \& Naify, 2002, pp. 297-316. Discuti esta questão mais aprofundadamente em VIEGAS, Susana de Matos. "A long-term perspective on belonging: the pleasure of 'eating' manioc beer among the Tupinambá Indians of Olivença (Bahia, Brazil)". Seminário Apresentado no Friday Seminars - "Research Seminar on Anthropological Theory. Departamento de Antropologia, London School of Economics, Londres. UK. 2005.

${ }^{9}$ Designo estes lugares de "unidades compósitas de residência", na medida em que cada lugar é constituído por diversas casas que mantêm entre si relações simultâneas de dependência e independência. O termo "unidade compósita de residência" corresponde grosso modo ao que por exemplo o antropólogo Mark Harris designa de cluster, no seu estudo da organização social dos caboclos das terras ribeirinhas de Parus na Amazônia: "uma rede densa de casas multi-familiares, organizadas em torno de um casal" HARRIS, Mark. Life on the Amazon: the anthropology of a Brazilian peasant village. Oxford: Oxford University Press, 2000, p. 85. De fato, cada "unidade compósita de residência" é habitada, normalmente, pelo que se convencionou designar em antropologia de "família extensa", já que em cada lugar habitam pelo menos o casal principal que o fundou ou que é descendente direto de quem o fundou e em casas separadas seus filhos com respectivos descendentes. 
A região de Olivença situa-se no sul do estado da Bahia, entre os paralelos $14^{\circ} 26^{\prime}$ Sul e a linha da costa, e entre os meridianos $39^{\circ} 02^{\prime}$ e $39^{\circ} 30^{\prime}$, fazendo parte do município de Ilhéus. A região faz parte da faixa de Mata Atlântica do sul da Bahia, apresentando considerável diversidade em termos de recursos naturais, abrangendo áreas de solo muito pobre - Tropudultus Variação Cururupe, solos com horizonte óxido - B Latossólico, Haplorthoxs variação tabuleiro - e apenas uma faixa menor de solos mais ricos, como aquela que se inscreve na chamada região cacaueira do sul da Bahia.

Histórica e culturalmente os índios que habitam atualmente na região de Olivença pertencem inequivocamente à grande família Tupi, ainda que não estejamos aqui a recorrer ao termo Tupi como uma categorização lingüística, mas como uma identificação social, cultural e histórica, já que os Tupinambá de Olivença não falam qualquer derivação da língua Tupi. O seu modo de vida aproxima-se, porém, em múltiplas frentes, de socialidades ameríndias, em alguns casos especificamente Tupi, como tive oportunidade de verificar no que respeita às filosofias sociais que orientam as suas vidas, entre as quais a ênfase na necessidade de uma vigilância diária da troca de afetos e o sentido constitutivo de socialidade através da alimentação são de relevar para o presente $\operatorname{argumento}^{10}$.

As fontes e estudos históricos mais confiáveis permitem-nos avaliar com segurança que estamos perante índios Tupi. Serafim Leite, por exemplo, insiste na preponderância Tupi na região, ao referir que no final do século XVII a aldeia de Nossa Senhora da Escada "era constituída por índios Tabajaras e Tupinaquins, 130 casais, que Silveira individualiza em 600 índios" ${ }^{11}$. É ainda a favor desse etnônimo que se pronuncia o Ouvidor da Bahia Luís Freire de Veras em 1768, não referindo sequer a existência de outro povo na vila de Olivença que ele próprio erigiu, dizendo que "eram os índios da nação Tupy e falavam a língua chamada de geral dos índios" ${ }^{12}$. No início do século XIX esta mesma identificação é corroborada pelo naturalista Wied-Neuwied no livro Viagem ao Brasil, quando passa nesta região de Olivença ${ }^{13}$. John Monteiro tem sublinhado que a divisão entre Tupiniquins e Tupinambá se tem constituído

\footnotetext{
${ }^{10}$ Cf. VIEGAS, Socialidades Tupi, op.cit.

${ }^{11}$ Cf. LEITE, "Ilhéus", op.cit., p. 224.

${ }^{12}$ Citado em DIAS, "Inserção Econômica”, p. 16.

${ }^{13}$ Wied-Neuwied citado em SALES, Fernando. Memória de Ilhéus. São Paulo: Editora Nacional, 1981, pp. 74-75.
} 
apenas a partir dos estudos arqueológicos e etno-históricos sobre a origem e dispersão da "cultura Tupi-Guarani”" e suas diferentes tradições históricas, chegando-se à divisão dos Tupi-Guarani do século XVI em Tupinambá - os quais se localizariam entre a capitania de São Vicente e a boca do Amazonas - e os Guarani para sul de São Vicente. De acordo com esta divisória, os índios habitantes na região de Ilhéus nesse período seriam Aimoré e Tupinambá ${ }^{14}$.

Como tem sido mostrado por Manuela Carneiro da Cunha ou John Monteiro, no século XIX as descrições dos Tupinambá informaram uma "nostalgia imperialista" da sociedade moderna: um sentimento de perda que romantiza a diferença cultural e a projeta para o passado ${ }^{15}$. Como refere Carneiro da Cunha são “os Tupi e os Guarani, já então virtualmente extintos ou supostamente assimilados, que figuram por excelência na auto-imagem que o Brasil faz de si mesmo. É o caboclo nacionalista da Bahia. É o índio bom e convenientemente é o índio morto"16. John Monteiro considera ter sido em pleno período de etnogênese que os Tupinambá da costa ocupam o lugar do passado de uma nova nação do Novo Mundo:

"Não tendo as ruínas espetaculares das civilizações antigas (...) e deparando-se com um conflito aberto com sociedades nativas existentes, a geração de elite que cresceu com o Imperador Dom Pedro II começou a desenvolver uma mitografia nacional que colocou no centro o nobre, valente e (especialmente) extinto Tupi da costa". ${ }^{17}$

Perante um fundo histórico desta natureza, seria de esperar que o impacto do reconhecimento da existência de índios Tupinambá costeiros em pleno século

\footnotetext{
${ }^{14}$ MONTEIRO, John. "The Crises and Transformations of Invaded Societies: coastal Brazil in the sixteenth century". In: The Cambridge History of the Native Peoples of the Americas. Salomon, Frank \& Stuart B. Schwartz (orgs.). Vol III (Part 1): South America. Cambridge: Cambridge University Press, 1999, pp. 976-977.

${ }^{15}$ CUNHA, Manuela Carneiro da. "Política Indigenista no século XIX.” In: CUNHA, Manuela Carneiro da, (org.). História dos Índios no Brasil. São Paulo: Companhia das Letras, 1992, pp. 133-154 e MONTEIRO, John. "The Heathen Castes of Sixteenth-Century Portuguese America: unity, diversity, and the Invention of Brazilian Indians". Hispanic American Historical Review 80 (4), 2000, pp. 698-719. Sobre a idéia de "nostalgia imperialista", ver ROSALDO, Renato. "Imperialist Nostalgia". Representations 26, 1989. pp. 107-122.

${ }^{16}$ CUNHA, "Política Indigenista", op.cit., p. 136.

${ }^{17}$ MONTEIRO, “The Heathen Castes", op.cit., p. 710.
} 
XXI oscilasse, como tem vindo a suceder, entre o encanto, a surpresa, o repúdio e o descrédito. $\mathrm{O}$ fato de viverem num espaço geográfico que não corresponde, no imaginário nacional, à região onde os índios existem hoje (a Amazônia) e sim no passado (a costa nordestina do Brasil) coloca ainda maior resistência a uma moldura cognitiva que por um lado assumiu a extinção dos Tupi da costa, e por outro re-significou o nordeste como uma região de população assimilada ${ }^{18}$. A experiência de relação dos Tupinambá de Olivença com outros povos indígenas tem os confrontado, como aconteceu em 2005 quando se juntaram a índios vindos de várias partes do Brasil nos Jogos Indígenas, ocorridos em Porto Seguro, com uma recepção de surpresa e felicidade: "ainda estão aí?!"

A história de ocupação e significação do território habitado pelos Tupinambá de Olivença é importante para situar a sua existência na atualidade. A região de Olivença é habitada sensivelmente por 2500 índios e 11.000 não-índios. Olivença está hoje conectada à cidade de Ilhéus e ao pequeno centro urbano e rural de Una, a cerca de seis quilômetros ao sul, ao mesmo tempo que os índios habitantes das regiões de fronteira montanhosa têm vindo a criar relações com outros centros urbanos, entre os quais se destaca Buerarema. Os Tupinambá de Olivença vivem em sete localidades. Junto da costa, numa faixa percentual significativa do território, os Tupinambá são os mais exímios extrativistas de piaçaba das palmeiras que nessa região são nativas. Em alguns casos é com esse conhecimento que se tornam assalariados de fazendeiros e noutros casos coletam e vendem diretamente a piaçaba. Estima-se que há pelo menos um século a colheita de piaçaba seja das atividades que melhor favorece o acesso dos Tupinambá ao mercado, primeiro através de um sistema de aviamento cujas implicações abordei noutro lugar e atualmente como assalariados ou como vendedores de piaçaba a intermediários que percorrem as estradas de terra batida da região ${ }^{19}$.

O trabalho agrícola realizado pelos Tupinambá de Olivença está normalmente associado ao cultivo de mandioca. Numa destas localidades onde concentrei o primeiro estudo etnográfico pude historiar a ocupação do território

\footnotetext{
${ }^{18}$ Cf. DANTAS, Beatriz G., CARVALHO, Maria Rosário e SAMPAIO, José Augusto. "Os Povos Indígenas no Nordeste Brasileiro: um esboço histórico.” In: CUNHA, Manuela Carneiro da (org.). História dos Índios no Brasil. São Paulo: Companhia das Letras. 1992, pp. 431-456. ${ }^{19}$ VIEGAS, Susana de Matos. "Compatibilidades Equívocas: A permuta de terra entre brancos e índios Tupi na costa sul da Bahia” In: FAUSTO, C. e MONTEIRO, J. (orgs.). Tempos Índios: Narrativas do Novo Mundo. Lisboa: Assírio e Alvim, no prelo.
} 
e concluir que o processamento de mandioca para fazer farinha foi um recurso laboral de grande sucesso na década de 1960, tendo começado com a iniciativa de um fazendeiro que se apercebeu da mais-valia da mão-de-obra indígena, produzindo farinha para venda. Nessa época mais ainda do que atualmente, muitos índios fabricavam e vendiam diretamente a sua farinha. O reconhecimento da qualidade da farinha produzida na região de Olivença e muito especificamente em Sapucaeira é uma garantia de escoamento do produto no mercado de Ilhéus. Numa região onde a produção de mandioca é muito comum e historicamente profunda a fama ganha pela farinha dos Tupinambá de Olivença projeta-se na tabuleta de um comércio de venda de farinha num bairro popular de Ilhéus onde se chamam clientes anunciando: "vendemos farinha de Sapucaeira"20.

Entre outras fontes de rendimento dos Tupinambá de Olivença estão pequenos e muito variados comércios: de coco ou de cocada no período de veraneio de população vinda de Ilhéus ou do interior de Minas Gerais, de molhos de piaçaba e de artesanato. Nunca conheci um índio que vivesse de vender peixe, ou caça, ou qualquer tipo de fruto (como o mamão, a banana ou mesmo seringa) - cultivos muito comuns nas fazendas da região - e menos ainda da venda de gado ou da produção de cacau, rarefeita mas existente na região.

O território que os Tupinambá de Olivença habitam reproduz um conjunto multifacetado de uso dos recursos naturais que é intrínseco à sua forma de habitação dispersa. Mas a mandioca e seus derivados ganham um lugar de destaque na sua vida. Alimentar-se envolve inevitavelmente ingerir um qualquer preparado de mandioca. Põe-se farinha de mandioca em água ou caldo de peixe para fazer pilão, ou para fazer escaldado, come-se farinha com coco, farinha no café, aipim cozido pela manhã. O beiju não é apenas mais um alimento, mas um dos preferidos pelos Tupinambá, estando ligado a diversas elaborações simbólicas ${ }^{21}$. Em suma, o cultivo e alimentação ligados com a mandioca ocupam um lugar central na vida dos Tupinambá, inscrevendo-se em disposições alimentares que fazem desejar certos alimentos. Entre estes está a cerveja de mandioca.

\footnotetext{
${ }^{20}$ Cf. DIAS, "A Inserção Econômica”, op.cit.

${ }^{21}$ Cf. VIEGAS, Socialidades Tupi, op.cit.
} 


\section{Persistência}

Aquilo a que os Tupinambá de Olivença chamam de giroba é uma bebida branca e leitosa, preparada com mandioca mansa (Manihot esculenta Cranzt), normalmente aipim ou mandioca Caravela, ambas com um nível de cianeto em raiz fresca muitíssimo baixo ${ }^{22}$. Este fato explica a simplicidade do processo, se comparado com as múltiplas e complexas formas de preparação que conhecemos entre os povos contemporâneos da Amazônia, os quais usam com maior freqüência mandioca com níveis mais elevados de cianeto.

Os Tupinambá concordariam conosco se lhes disséssemos que ninguém toma a decisão de preparar giroba para si próprio. A giroba é quase invariavelmente preparada por mulheres e sempre a pedido de outrem. Como em muitos outros contextos ameríndios, a ligação entre quem prepara e quem consome giroba é muito freqüentemente intermediada pela relação entre esposa e esposo. Este fato tem levado diversos antropólogos a notar a importância desta bebida na complementaridade das relações entre sexos, particularmente no casamento ${ }^{23}$.

A preparação da giroba pode ser feita por várias mulheres. Inicia-se com a raspagem do aipim, que é de seguida colocado numa panela a cozer no fogo, até que amoleça. Deixa-se depois esfriar e verte-se num pilão ou um recipiente de alumínio. Os Tupinambá preferem o pilão de madeira, mas nem sempre as unidades domésticas possuem um pilão suficientemente grande para amachucar

\footnotetext{
${ }^{22}$ Cf. BORGES, Maria de Fátima, FUKUDA, Wânia Maria Gonçalves e ROSSETI, Adroaldo Guimarães. "Avaliação de variedades de mandioca para consumo humano". Pesquisa Agropecuária Brasileira, Brasília, Volume 37 (11), 2002, p. 1560. ERIKSON, “L'art de couler”, cit., p. 244, diferencia a cor das cervejas de acordo com o tipo de tubérculo usado: a cor da cerveja de mandioca é branca, diferindo da de milho que será amarela e a de inhame violeta. Segundo Tânia Stolze Lima (comunicação pessoal) só mesmo a cerveja feita com aipim pode ficar branca. O Cauim dos Yudjá é "cor de café com leite", assim como dos Waiãpi; a cerveja dos Piro e dos Aruaque subandinos é cor-de-rosa e a dos Ashaninca (brasileiros) branca e feita de aipim.

${ }^{23}$ Ver GOW, Peter. "The Perverse Child: Desire in a Native Amazonian Subsistence Economy." Man 24 (4), 1989, p. 570; GUZMÁN, María Antonieta. Para que la yuca beba nuestra sangre. Trabajo, género y parentesco en una comunidad quichua de la Amazonía ecuatoriana. Quito: Abya-Yala, 1997; UZENDOSKI, Michael A. "Manioc beer and meat: value, reproduction and cosmic substance among the Napo Runa of the Ecuadorian Amazon". Journal of the Anthropological Royal Institute (n.s.)10, 2004, pp. 883-902, p. 888; e LIMA, Tânia Stolze. A Parte do Cauim: etnografia Juruna. Tese de doutorado. Rio de Janeiro. PPGAS: Universidade Federal do Rio de Janeiro. 1995, pp. 288-289.
} 
a quantidade mínima de vinte litros de giroba que se faz de cada vez. À medida que se vai pisando o aipim, junta-se água, sendo necessário ser bastante vigoroso nesta tarefa porque o aipim, depois de cozido, deita uma goma que vai grudando a massa ao tacho - tarefa facilitada com o pilão, porque a massa se descola da madeira. A massa volta então ao fogo para ligar, após o que é vertida para uma vasilha. Este é o momento crucial do processo, pois é neste repouso que a bebida vai fermentar ${ }^{24}$. O fato do recipiente ser de barro ou de no passado se verter a bebida em cabaças de grandes dimensões (sobre as quais falaremos mais à frente) são os diversos elementos implicados na fermentação. Os Tupinambá de Olivença associam a maior fermentação da bebida ao sabor mais amargo, isto é, "azedo" e por isso falam em "giroba doce" e "giroba azeda". Este último termo é quase um pleonasmo, já que por definição a giroba é para os Tupinambá uma bebida fermentada e azeda. Mas a diferença está em que em alguns casos se adiciona açúcar, por várias razões que trataremos mais à frente. Os Tupinambá de Olivença fazem ainda menção especial à "giroba de três dias", reforçando uma correlação direta entre o tempo de repouso da bebida (ao calor do clima da região, sem qualquer preocupação de refrigeração) e o aumento do grau de fermentação ${ }^{25}$. Apesar de esta exposição à temperatura

\footnotetext{
${ }^{24}$ Uma das descrições mais concisas do processo foi-me feita por uma mulher nos seus quarenta anos de idade: "Eu arranco ela, descasco ela, bato com ela miudinha e boto para cozinhar. Aí quando está cozida a pessoa bota dentro de uma bacia e pisa ela com um pilãozinho, com a mão de pilão. Aí depois que faz aquela papa, a pessoa bota água, envolve ela toda e despeja ou num caldeirão, ou num catuto, ou num pote, e bota ela lá para avinhar. Quando ela avinha, aí já está na hora da pessoa tomar.

- E tem pessoas que deixam ficar fermentando uns dias?

- Deixa sim. Quando é muito mesmo, a pessoa começa a tomar e quanto mais a pessoa toma é que ela fermenta mesmo. E volta ao fogo".

${ }^{25}$ Esta definição dos paladares de cervejas de mandioca do doce ou insípido até ao amargo e azedo consoante o grau de fermentação que em parte se afere do número de dias em que a bebida fica a fermentar é relativamente comum (cf. ERIKSON, "L'art de couler", op cit., p. 246; LIMA, A Parte do Cauim, op.cit., pp. 296-297). Para o caso dos Yudjá, Lima especifica esta sequiência de paladares: "os sabores do cauim vão de par com o processo da fermentação, partindo do "insípido" (imã) e do "doce" ( $\left.\ddot{i}^{\circ} \tilde{a} k u\right)$, atingindo o "amargo" ou "forte" ( $i$ 'ahu), e finalmente o "azedo" ou "podre" ( $i \approx a d ¥)$ " (LIMA, Tânia Stolze. Um peixe olhou para mim: o povo Yudjá e a perspectiva. São Paulo: Editora Unesp. 2005, pp. 294-295). Erikson chama a atenção para mais um aspecto interessante por relação aos paladares: o fato do gosto da cerveja depender em grande parte da levedura presente no ambiente em que é preparada, sendo por isso que qualquer tentativa de as preparar em Paris estará sempre condenada ao fracasso.
} 
ambiente já assegurar uma temperatura tépida, a etapa final da preparação da giroba consiste em "esquentar" a bebida antes de beber, porque os Tupinambá de Olivença têm uma preferência muito explícita por beberem a giroba.

A mandioca mansa cultiva-se com facilidade e sucesso perante as condições de solo e clima existentes em Olivença e a preferência dos Tupinambá de Olivença por este tipo de mandioca para fazer cerveja explica que o processamento da giroba seja mais simplificado do que aqueles descritos para muitos outros contextos ameríndios, onde se usa mandioca brava ${ }^{26}$. Não deixa de ser igualmente significativo, contudo, que exista um decalque entre o processo usado hoje pelos Tupinambá de Olivença e o procedimento descrito por Hans Staden para a preparação da cerveja de mandioca pelos Tupinambá do Rio de Janeiro no século XVI:

Tupinambá de Olivença:

1. Cozer a mandioca no fogo.

2. Deixar esfriar

3. Pisar no pilão

4. Voltar a cozer no fogo acrescentando água

5. Verter para uma vasilha onde fica a descansar/fermentar

Descrição de Hans Staden (século XVI) para os Tupinambá ${ }^{27}$ :

1. Cozinhar a mandioca no fogo

2. Deixar esfriar

3. Mascar

4. Voltar a cozer no fogo, acrescentando água

5. Verter para uma vasilha onde fica a descansar/fermentar

Teremos que deixar para mais adiante as considerações sobre a diferença entre "mascar" e "pisar" a massa, bem como sobre a vasilha utilizada para

\footnotetext{
${ }^{26}$ Ver, por exemplo, HUGH-JONES, Christine. From the Milk River: spatial and temporal processes. Cambridge: Cambridge University Press, 1988, pp. 174-181; JACKSON, Jean. The Fish People: Linguistic Exogamy nad Tukanoan Identity in Northwest Amazonia. Cambridge: Cambridge University Press, 1983; e LIMA, Um Peixe Olhou para Mim, pp. 287-294.

${ }^{27}$ STADEN, Hans. Duas Viagens ao Brasil: arrojadas aventuras no século XVI entre os antropófagos do Novo Mundo. Livro Segundo: A terra e seus habitantes. São Paulo: Ed. Martins, 1942, p. 265.
} 
fermentar. Mas importa desde já referir que face à pergunta sobre em que etapa do processo é que se fazia a mastigação, os adultos identificaram aquela de transformar o aipim em massa, hoje assegurada pelo pisar no pilão: "Só mastigava quem tinha os dentes perfeitos. Depois usou o pilão. Aí acabou."

Hans Staden não refere o fato dos Tupinambá aquecerem a bebida antes de a beberem. Porém, encontramos outras referências a este mesmo procedimento e, mais ainda, ao seu significado cultural para os Tupinambá habitantes na costa brasileira no século XVI. Léry, Thevet, Gabriel de Sousa e mesmo Montaigne explicitam o fato da bebida ser aquecida antes de se beber, porque os Tupinambá preferiam tomá-la morna:

"Quando querem divertir-se e principalmente quando matam com solenidade um prisioneiro de guerra para o comer, é seu costume (ao contrário do que fazemos com o vinho que desejamos fresco e límpido) beber o cauim amornado e a primeira coisa que fazem as mulheres é um pequeno fogo em torno dos potes de barro para aquecer a bebida" ${ }^{28}$.

É ainda Montaigne quem refere de forma peremptória que os Tupinambá bebem o cauim morno: "Sua bebida é feita de uma raiz e tem a cor dos nossos vinhos claretes. Só a bebem morna" ${ }^{29}$. Recorrendo tanto a Léry como a Thevet e Gabriel Soares de Sousa Florestan Fernandes também sublinha que: "nas cauinagens ultimavam a preparação das bebidas aquecendo-as ao fogo" 30 .

Entre os Tupinambá de Olivença são múltiplas as formas de insistir nesta preferência pela bebida morna, muitas vezes afirmada sob subterfúgios "Quem quiser bebe frio, quem não quiser esquenta. Aí fica gostosa!" ou, pelo contrário, de forma peremptória: "não usamos fria, só quente mesmo!". A preferência pela temperatura amornada da bebida fica bem clara tanto nas práticas atuais como nas descrições relativas ao passado: "Deixava azedar e de manhã esquentava e bebia. Minha mãe enchia um caldeirão assim de giroba, botava para esquentar lá no fogo

\footnotetext{
${ }^{28}$ LÉRY, Jean de. "Das Grossas Raízes e do Milho com que os selvagens fabricam a farinha, comida em lugar do pão; da bebida a que chamam Cauim”. In: Viagem à Terra do Brasil. São Paulo. Editora da Universidade de São Paulo. 1972 [1578], p. 90.

${ }^{29}$ MONTAIGNE, Michel de. "Dos Canibais". Os Ensaios: Livro I. São Paulo: Martins Fontes, 2000 [1579], p. 310)

${ }^{30}$ FERNANDES, Florestan. A Organização Social dos Tupinambá. Brasília: Editora UnB, 1989 [1948], p. 114.
} 
e quando estava morninho dava para todo o mundo beber" (homem Tupinambá de Olivença com cerca de quarenta e cinco anos, residente no Curupitanga); "Eu mesmo, eu e minha família não usa fria não, só quente mesmo (...) Bota na panela e aquece. Gosto assim morna, quente de mais não gosto não" (mulher Tupinambá de Olivença, cinqüenta anos de idade, residente em Sapucaeira/Olivença). Veremos mais à frente como esta preferência pela bebida morna faz parte do campo de prazeres associados à giroba, sendo mais importante notar de momento a identificação desta mesma preferência com a dos Tupinambá do século XVI ${ }^{31}$.

A relação entre o fogo e a giroba é estreita a muitos níveis. Apesar da giroba ser líquida, para os Tupinambá de Olivença é "bebida como um alimento, uma alimentação", de uma forma muito mais literal do que acontece, por exemplo, com o leite materno, sobre o qual se diz que alimenta o nenê, mas não que se come leite materno. No caso da giroba as expressões usadas para descrever o seu consumo são, literalmente, "comer giroba". De fato, o valor nutritivo e fortificante da giroba começa por se explicar pelo fato de ser a bebida que substitui o leite materno no período de desmame. A este propósito uma índia com seis filhos já adultos disse-me que quando os filhos eram pequenos, a meio da noite ela acordava-os para lhes dar uma colher de giroba de forma a garantir que crescessem fortes e saudáveis. Não há nenhuma evidência de que efetivamente as crianças sejam ou fossem acordadas para beber giroba, mas aquilo que ela quis enfatizar com esta referência foi o valor fortificante e nutritivo da giroba ${ }^{32}$.

\footnotetext{
${ }^{31}$ Agradeço a Tânia Stolze Lima o comentário a uma versão anterior deste texto onde mencionou a singularidade da preferência dos Tupinambá de Olivença pela bebida morna contrastante com os hábitos indígenas na Amazônia, tendo sido em resultado desta indicação e incentivo que aprofundei a minha reflexão sobre as fontes relativas aos Tupinambá do século XVI.

${ }^{32}$ De fato, o teor nutritivo da mandioca aumenta com a fermentação. A mandioca não-fermentada possui $1,5 \%$ de proteínas, enquanto que fermentada as proteínas aumentam para $8 \%$ contendo, ainda, "minerais nobres como selênio, cromo e cobre" (cf. FERNANDES, Selvagens Bebedeiras, op. cit., pp. 53-54). Encontramos outras referências relevantes sobre o significado nutritivo das bebidas fermentadas em contextos sul-ameríndios. Goldman sublinha que para os Tukano Cubeo da região do Vaupés na Colômbia "a chicha também é considerada uma comida" (GOLDMAN, Cubeo Hehénewa Religious Thought, op.cit., p. 143) e que ingerir chicha é visto pelos Cubeo como indispensável para fortalecer o coração de uma pessoa e dar-lhe energia e uma vida longa (p. 355). Num artigo recentemente publicado, Uzendoski diz que para os Napo Runa do Equador a mandioca, especialmente a cerveja de mandioca, é uma fonte de energia e força (UZENDOSKI, "Manioc Beer and Meat", cit., pp. 883, 887). No geral, a Chicha é vista como um fortificante no Equador (GUZMÁN, Para que la yuca, op. cit.), sendo atribuída a ela a capacidade de dar força aos homens que trabalham em sistema de entreajuda nas conhecidas "festas" das mingas onde à reciprocidade alargada se junta a troca direta de trabalho por cervejas fermentadas (ver também BELAÚNDE, Viviendo bién, p. 172.
} 
A nutrição não é aqui vista num sentido estrito de satisfação de necessidades, mas ao mesmo tempo que integra essa perspectiva insere-a num quadro mais amplo da constituição de corpos saudáveis. Muitas são as histórias autobiográficas de adultos que recordam como na infância recuperaram de fases de maior fragilidade física com a ingestão de giroba. Logo no primeiro período longo de trabalho de campo, em 1997-1998, ouvi repetidamente: "a giroba faz caboclos fortes" ou "foi assim que se criaram os caboclos forte. Foi com essa bebida de giroba".

A qualidade medicinal que é hoje expressa de forma literal pelos Tupinambá de Olivença quando dizem que a giroba é "um remédio", que "dá saúde" e que "fortalece a pessoa" expressa-se, entre outros, nas qualidades de resolução ou prevenção de doenças de fígado e de estômago. Uma mulher que em 1998 tinha cerca de cinqüenta anos de idade chegou a assegurar-me que em determinada altura até os médicos de Ilhéus receitariam giroba para doenças desta natureza. Na verdade, são conhecidos os efeitos medicinais de preparados fermentados ${ }^{33}$ mas como veremos à frente este efeito de "remédio" é atingido apenas quando a giroba é tomada em grandes quantidades até provocar o vômito e consequentemente esvaziar o estômago "limpando o corpo".

O contexto convivial em que se ingere giroba é central para a compreensão dos seus sentidos tanto para os Tupinambá de Olivença como para uma contextualização histórica e comparativa. O grupo de pessoas que partilha a giroba não é o grupo comensal quotidiano de uma casa. A giroba tende a ser consumida não apenas entre aqueles que habitam diversas casas de uma unidade compósita de residência ou lugar, mas ainda entre os parentes que habitam noutras unidades de residência, em ocasiões de convívio alargado.

Assim aconteceu, por exemplo, em 1998 quando uma índia idosa que visitava freqüentemente a casa onde eu pernoitava (pertencente a um casal de uma índia com um não-índio), solicitou à anfitriã (sua parente) que fizesse giroba para o dia da chegada da bandeira do Espírito Santo. Fez o pedido de forma rogada e inesperada para quem, como ela, ficava horas a fio inerte, no banco corrido dos fundos da casa, em silêncio, a observar o movimento e a conversa dos habitantes e de outros visitantes (normalmente não-índios) que anunciavam em voz alta mal se aproximavam da casa que vinham para "prosar". Esta mulher fazia justiça a uma das idéias que circula na região sobre o caráter "cismado" dos caboclos, metidos consigo próprios, pouco faladores. Naquele

${ }^{33}$ Cf. FERNANDES, Selvagens Bebedeiras, op.cit., p. 291. 
dia, ao solicitar que preparassem giroba não obteve reação da anfitriã, mas a filha habitante na outra casa do mesmo lugar ofereceu-se para a fazer, exigindo apenas que fosse ela (parente visitante) a trazer o aipim da sua própria roça.

No dia da chegada da bandeira a giroba bebeu-se logo pela manhã, muito antes do frenesim de preparação do almoço. Tanto esta índia idosa como as crianças residentes na unidade compósita de residência beberam-na com gosto. A chegada da bandeira fez-se anunciar pelo som de um tambor. Os "romeiros" entraram na casa, tocaram e cantaram, seguindo uma postura ordenada, mais aproximada à de uma parada do que à de uma dança. Abriram um saco de tecido vermelho aveludado (o mesmo tecido da bandeira) e as pessoas presentes intervieram, enrolando-se e desenrolando-se no pano da bandeira em duas voltas rápidas. De seguida largaram uma ou duas moedas dentro do saco. Naquele dia, os "romeiros" almoçavam ali mesmo em casa, mas até à sua partida, e depois dela, em momento algum houve ocasião para uma convivialidade mais expansiva como vi tantas vezes acontecer em serões ou mesmo em reuniões de outra natureza social e política, nas quais o convívio presume música de rádio em som alto, algazarra, falar alto, dar abraços inesperados e tocarem-se os corpos ${ }^{34}$.

Mais recentemente vi fazer-se giroba para as reuniões realizadas no âmbito de debates políticos sobre a reivindicação de direitos à terra, algumas delas organizadas pela equipe da FUNAI que eu coordenei e pelas lideranças, no âmbito do trabalho de campo para a identificação da terra indígena. As reuniões dão azo às mais diversas situações que vão dos discursos proferidos de forma solene pelas lideranças, ao convívio informal que resulta das refeições, dos intervalos, dos banhos no rio, da pernoita quando se partilha o chão das casas e se trocam palavras ensonadas sobre a vida, as crianças ou a terra. Para além destas situações, estas reuniões abrem e encerram com um momento "ritual", quando se dança e canta o Porancim ${ }^{35}$. O Porancim começa com uma dança

\footnotetext{
${ }^{34}$ Cf. VIEGAS, Socialidades Tupi, op.cit.

${ }^{35}$ O Porancim poderá ser descrito como o Toré dos Tupinambá de Olivença. Nasceu de reuniões com outros índios da Bahia, Espírito Santo e Minas Gerais, nas quais foram instruídos sobre esta forma de dança e cântico que articula todos os índios do nordeste. Sobre o Toré veja-se ARRUTI, José Maurício Andion. 1999. “A Árvore Pankararu: fluxos e metáforas da emergência étnica no sertão de São Francisco". In: OLIVEIRA, João Pacheco (org). A Viagem da Volta: etnicidade, política e reelaboração cultural no Nordeste indígena. Rio de Janeiro: Contra Capa, 1999, p. 243 e GRUNEWALD, Rodrigo de Azeredo. Os Índios do Descobrimento: tradição e turismo. Rio de Janeiro: Contra Capa, 2001.
} 
em alinhamento circular. Parte substancial da dança consiste em bater os pés no chão com força e de forma ritmada, curvando ligeiramente o corpo para a frente, volvendo o braço com maracás e cantando músicas e letras repetitivas, que os Tupinambá de Olivença têm vindo a criar com enorme sucesso desde o ano 2000. Das diversas vezes em que participei destas reuniões e assisti ao Porancim aconteceu haver num caso uma e noutro outra mulher (entre os vinte a trinta dançantes) que entraram em transe. Quando a reunião se dá em locais com menor vigilância pública, um dos índios mais idosos, fuma o seu cachimbo. Como ele próprio confirmou quando falamos sobre o último transe a que assistira, o Porancim é um dos contextos através dos quais os Tupinambá de Olivença esperam encontrar o seu pajé. Em várias destas reuniões vi usar-se giroba, mas em nenhuma delas se associou a ingestão de giroba ao Porancim. É antes nos momentos de decisões e consensos, em intervalos nos debates e discursos, que aparece o recipiente com giroba. Desde que o processo de reivindicação da terra indígena Tupinambá de Olivença começou em 2003 tem vindo a aumentar o consumo de giroba nas reuniões e a expandir-se para consumidores mais jovens que não a bebiam ou preparavam usualmente.

$\mathrm{O}$ efeito de exo-bebida desta cerveja de mandioca fica aqui, portanto, explicitada, assim como a identificação do consumo de giroba com ocasiões de convívio de sociabilidade alargada, mas de natureza não-festiva e não-ritual. $\mathrm{Na}$ verdade, como mostrei noutro lugar, nestas ocasiões festivas que envolvem dança, música e grande agitação emotiva o que se bebe é cachaça ou licores feitos com cachaça, não sendo estas ocasiões para se beber giroba ${ }^{36}$.

Cabe-nos então fazer algumas considerações sobre a relação entre as práticas de consumo da giroba pelos Tupinambá de Olivença, as conhecidas festas exuberantes das cauinagens e o caráter inebriante das bebidas fermentadas. Por mais que tenha insistido com os Tupinambá de Olivença, em muitas e variadas situações, sobre a possibilidade da giroba provocar embriaguez ela foi-me sistematicamente negada. Cheguei a sugerir se ao beber-se giroba não se ficava tonto como quando se consome cachaça, mas a relação entre uma e outra coisa foi vista pelos diversos índios a quem coloquei a questão como absolutamente aberrante. A associação da giroba a estados inebriantes constituiria um definitivo erro etnográfico no caso dos Tupinambá de Olivença para quem a cachaça é a

\footnotetext{
${ }^{36}$ Cf. VIEGAS, "Eating with your favourite mother", op.cit, e Socialidades Tupi, op.cit.
} 
bebida inebriante por excelência. Em 1997 e 1998 ouvi diversas vezes afins não-índios dizer em relação aos índios que, quando constava que havia "giroba $e$ cachaça" seria garantido aparecerem logo "caboclos". Para alguns índios esta diretiva é uma ofensiva, já que o hábito de beber cachaça está por demais consolidado entre todos os habitantes índios e não-índios da região. De fato, desde 1998 que vi acirrarem-se debates entre os Tupinambá de Olivença sobre a possibilidade de se aceitar que a bebida de cachaça fizesse parte da "cultura indígena". Havia quem contra-argumentasse exatamente com o princípio de que as "bebidas tradicionais" que tinham são "a giroba".

Do ponto de vista comparativo, a questão que nos é colocada pelos sentidos atribuídos pelos Tupinambá de Olivença à giroba é que se trata de uma bebida fermentada ou, mais ainda, definicionalmente fermentada, inscrita como uma bebida-comida que é ingerida em contextos não rituais nem festivos, quando as etnografias americanistas normalmente associam as bebidas-comidas a preparados de baixa ou nula fermentação, de consumo doméstico ${ }^{37}$. O uso não-festivo de uma bebida considerada à partida como fermentada é o que parece destoar aqui. Mas ao mesmo tempo se tem cada vez mais sublinhado que o teor alcoólico de muitos dos cauins usados em convivialidades rituais e festivas é muito baixo. Numa das mais sofisticadas e espantosas descrições de cauinagens onde o estado de "embriaguez" se atinge de forma absoluta, Tânia Stolze Lima adverte que "o baixo teor alcoólico da dubia [cerveja fermentada dos Yudjá usada para a cauinagem] requer que se bebam quantidades impressionantes" e que esta abundância e exuberância são definicionais do que é a cauinagem para os Yudjá:

"os homens se orgulham de beber demais, entusiasmam-se quando seu
estômago se torna sensivelmente protuberante. Ultrapassar limites é um
desejo notável em muitos planos da cauinagem, de forma que tudo será
elevado à potência". ${ }^{38}$

Já por relação ao uso do cauim pelos Tupinambá do século XVI, João Azevedo Fernandes defendeu recentemente que se trata de um caso flagrante

\footnotetext{
${ }^{37}$ Cf. VIVEIROS DE CASTRO, "Apresentação", op.cit., p. XXIV; UZENDOSKI, "Manioc Beer and Meat", op.cit., p. 888.

${ }^{38}$ LIMA, Um Peixo Olhou para Mim, op.cit., p. 219.
} 
do uso de uma substância de "fraca capacidade de alteração da consciência", sendo os fatores culturais que conferem sentidos mais fortes para as sensações e comportamentos verificados nas cauinagens ${ }^{39}$.

Entre as fontes históricas que tive oportunidade de consultar ou conhecer importa realçar tanto a referência a uma bebida fermentada "doméstica" usada pelos índios de Olivença no século XVIII, quanto à efetiva importância da "aguardente" e "cachaça" entre os Tupinambá de Olivença, de forma muito continuada desde pelo menos o século XVIII. Enquanto Ouvidor da Comarca de Ilhéus, Baltasar da Silva Lisboa escreveu vários comentários à vida dos índios que habitavam em Olivença. Num desses trechos, datado de 1799, faz alusão ao fato de no passado um viajante anônimo ter justificado o caráter pacifico dos índios de Olivença contrastando-o com o de outros índios da região, quando relata ter entrado na casa de um índio, num passeio que fez pela região do rio Acuípe, e lhe ter bebido o cauym sem que o índio, dormitando, tivesse sequer reagido:

"Com os vários assaltos do gentio, atemorizados os moradores se puseram em fugida, de sorte que hoje ali habitam alguns índios de Olivença e tendo saído alguns gentios, a ninguém tem causado dano, em forma tal que entrando em casa de um índio doméstico que encontraram dormindo, lhe beberam o Cau-ym, que é uma espécie de vinho feito de mandioca e aipim." ${ }^{40}$

Quanto à aguardente e/ou cachaça, as referências encontradas para Olivença corroboram o que se sabe sobre a introdução e sucesso da aguardente nos aldeamentos indígenas. Os jesuítas repudiaram inúmeras vezes estas práticas, mas a verdade é que os índios dos aldeamentos jesuítas muito cedo começaram a consumir aguardente, e o caso dos Tupinambá de Olivença permite-nos dizer que este terá sido, por ventura, o primeiro e mais persistente bem de consumo que quiseram adquirir. De fato, em 1692 um jesuíta interfere junto da Coroa con-

\footnotetext{
${ }^{39}$ FERNANDES, Selvagens Bebedeiras, op.cit., p. 327.

${ }^{40}$ LISBOA, Balthasar da Silva. "Officio do Ouvidor da comarca dos Ilheos Balthasar da Silva Lisboa para D. Rodrigo de Sousa Coutinho, no qual lhe communica uma interessante informação sobre a comarca de Ilhéos, a sua origem, a sua agricultura, commercio, população e preciosas matas, Cairú, 20 de março de 1799 (Documento:Caixa 98, n 19209, do Arquivo Histórico Ultramarino, Lisboa, Documento $\mathrm{n}^{\circ}$ 19209). In ALMEIDA, Inventário, op.cit., p. 108.
} 
seguindo que se emita uma ordem "para os Juízes dos Ilhéos não consentirem que se venda aguardente aos índios da aldeia dos Padres da Companhia" ${ }^{41}$. Num documento do século XVIII um funcionário administrativo do aparelho colonial português assinala o fato de muitos índios da vila de Olivença consumirem aguardente "em excesso", enquanto que o Ouvidor da comarca dos Ilheos, Balthasar da Silva Lisboa, refere que os índios de Olivença convertiam "os produtos de seu trabalho e indústria (...) em aguardente, ficando suas mulheres e filhos em total desamparo e miséria"42.

Nos finais do século XIX num registo de óbito do cartório de Olivença descreve-se minuciosamente como um índio morreu na seqüência de fazer o trajeto entre a cidade de Ilhéus e a vila parando em todos os bodegos onde bebia aguardente, acabando por sucumbir no último, onde foi encontrado morto. Por fim, nas descrições que os índios atualmente fazem dos processos de expropriação das terras nas décadas de 1930 a 1960 compreendemos que um produto por eles valorizado e adquirido a troco da entrega das suas roças era a cachaça ${ }^{43}$.

Este historial poderia levar-nos a concluir que o processo colonial produziu um desvio na sociabilidade "autêntica" de consumo da giroba ou cauim, agora substituído pela cachaça. Mas nada senão um pressuposto nos levaria a concluir isso. As curtas alusões ao caium nas fontes do século XVIII e as descrições dos Tupinambá levam-nos a crer que a giroba tem sido produzida e ingerida ao longo de todo este período, não se podendo, portanto, falar em substituição desta pela cachaça, mas pelo contrário na persistência de sentidos não-festivos e altamente valorizados de consumo da giroba como fortificante corporal. Do

\footnotetext{
${ }^{41}$ Antônio L. G. Coutinho, Ordens para os Juizes dos Ilhéos não consentirem que se venda aguardente aos índios da aldeia dos Padres da Companhia. 20/08/1692: Documentos históricos. Vol. 32, 1934, p. 299, citado em MARCIS, Teresinha. A "hecatombe de Olivença": Construção e reconstrução da identidade étnica. Dissertação de Mestrado, Universidade de Santa Cruz, Ilhéus, 2004, p. 44. Como nos lembra Fernandes, esta proibição ou luta contra a aguardente da parte dos padres não se restringia a uma missionação dos índios, mas alastrava-se aos colonos (FERNANDES, Selvagens Bebedeiras, op.cit., p. 312). Marta Amoroso, por seu lado, mostra-nos a relação específica entre a indústria da cana de açúcar e os processos de missionação, especificamente no caso dos Capuchinhos. AMOROSO, Marta. "Conquista do Paladar. Os Índios, o Império e as Promessas de Vida Eterna" In: FREIRE, José Ribamar Bessa (org.). Seminários FUNARTE Brasil 500 Anos. Nação/Região. Rio de Janeiro: FUNARTE. 2001.

42 "Officio do Ouvidor da comarca dos Ilheos Balthasar da Silva Lisboa “, op.cit, p. 110.

${ }^{43}$ VIEGAS, "Compatibilidades Equívocas”, op.cit.
} 
ponto de vista histórico, num singular e recente argumento, João Azevedo Fernandes chama a atenção para o fato da importância ritual, simbólica e tóxica das bebidas fermentadas ter ofuscado de tal forma a literatura sobre o uso dos cauins pelos Tupinambá dos séculos XVI e XVII que se tende a considerar secundário ou complementar o seu relevo medicinal e nutritivo. Fernandes lembra, por exemplo, que num clássico estudo sobre técnicas indígenas André Leroi-Gourhan sublinhara que a maioria das bebidas fermentadas eram muito fracas em álcool "desempenhando na maior parte dos casos um papel mais alimentar do que tóxico" 44 . Sustentando-se numa sofisticada abordagem comparativa, Fernandes acaba por defender peremptoriamente que "as cervejas de tipo cauim" consumidas difusamente pelos Tupinambá "constituíam um dos traços marcantes da sua cultura" sendo "bebidas de reduzido teor alcoólico, em que a embriaguez se origina muito mais de fatores culturais do que propriamente da potência etílica”. Curiosamente, José de Anchieta atribui ao fato dos Tupinambá do século XVI beberem a bebida "quente" o seu menor teor inebriante: "e depois de ferver dois dias o bebem quente, porque assim não lhes faz tanto mal nem os embebeda tanto ${ }^{45}$.

Fernandes mostra, ainda, que a técnica de salivação produz bebidas de baixo teor alcoólico, ao mesmo tempo que chama a atenção para a sua qualidade nutritiva. A célebre afirmação sobre o fato dos nativos não comerem quando bebem, ganha assim um duplo sentido: o da separação entre o momento de se comer e o de se beber, mas também o fato de não se comer depois de beber fermentado, porque o fermentado é uma comida que alimenta: "este vinho comumente o fazem grosso e basto, porque juntamente lhes serve de mantimento e quando bebem nenhuma outra cousa comem"46.

Para os Tupinambá de Olivença este significado nutritivo é muito importante. Como comentou certa vez comigo um homem idoso, numa conversa da qual participava também uma índia que era sua comadre:

"[A giroba serve] Para alimentar a gente. Beber. Toma aquilo e não sente fome nenhuma. Eu tomei dois copos de manhã comadre, e vim comer agora.

\footnotetext{
${ }^{44}$ Citado em FERNANDES, Selvagens Bebedeiras, op.cit., p. 54.

${ }^{45}$ FERNANDES, Selvagens Bebedeiras, op.cit., pp. 77-78.

${ }^{46}$ FERNANDES, Selvagens Bebedeiras, op.cit., pp. 77-78, inclusive citações de Anchieta.
} 
É bom, giroba. Eu ia até esquentar um bocado, mas não tem açúcar ainda. Estou esperando minha mulher trazer o açúcar e até agora não chegou”.

Mas como já vimos a propósito da giroba fazer caboclos fortes, este mesmo significado nutritivo conduz-nos a dimensões simbólicas e ontogênicas centrais à compreensão das socialidades dos Tupinambá de Olivença, não podendo ser visto, em suma, como uma dimensão secundária do significado da bebida ${ }^{47}$.

Os sentidos nutricionais e medicinais estão intrinsecamente ligados, no caso da giroba. Como ouvi dizer aos Tupinambá de Olivença a giroba "limpa a pessoa toda, ficando a pessoa sadia" apenas se for ingerida em grandes quantidades, até lotar o organismo, sendo referidos os efeitos do suor abundante, diuréticos e finalmente a expulsão de tudo o que há no estômago, vomitando. $\mathrm{O}$ efeito diurético é equiparado por alguns homens, com maior experiência de vida em meios urbanos, aos efeitos da cerveja industrial. Mas o efeito de "limpeza" provocado pela giroba atua diferentemente: por isso beber giroba é aconselhado para aclarar a urina de quem esteja com ela anormalmente escura. Já o suor não é apenas provocado por se ingerir grandes quantidades de bebida, mas também por ela ser ingerida quente num clima tropical com temperaturas altas e muita umidade. O vômito é o sinal final da limpeza corporal provocada pela giroba. Numa das afirmações mais expressivas que ouvi a este propósito, até pela forma como relaciona a linguagem da abundância com a do cristianismo, faz-se uma associação entre essa forma de beber muito e "a gula": "Às vezes os gulosos demais dizem: me dá mais, me dá mais. E daí a pouco está vomitando".

A relação entre a ingestão excessiva de bebida e o vômito tem sido apontada para vários contextos sul-ameríndios. Os Tupi Cinta-Larga associam estes excessos ao vômito reconhecendo, ao mesmo tempo, o valor nutricional da sua cerveja de mandioca dizendo que ela torna a pessoa mais gorda e forte, ao mesmo tempo que descrevem a chicha como uma bebida que em situações rituais os leva a

\footnotetext{
${ }^{47}$ Um dos elementos que torna a nutrição num elemento cultural é o fato de ser preparada por um triplo cozimento, fato igualmente observado por diversas fontes para os Tupinambá do século XVI (STADEN, Duas Viagens, op.cit., p. 165; SOARES DE SOUSA, Tratado Descritivo, op.cit., p. 311; LÉRY, Viagem à Terra do Brasil, op.cit., p. 90), tornando-se mesmo num "código alimentar" que produz identidade, como explorei noutro texto (VIEGAS, "Longterm perspective", op.cit.).
} 
$\operatorname{vomitar}^{48}$. Entre os Tupi Parakanã "o vômito produz a expulsão do que nos torna pesados, e por isso era também estimulado mecanicamente, cutucando-se a garganta com uma espécie de capim (marpe'awa)". O efeito do cauim não é identificado com a embriaguez, mas com "a leveza”: "Ele 'faz pular-voar' (mo-wewé), principalmente por ser um emético"49. João Azevedo Fernandes argumenta ainda que a descrição mais aproximada do efeito do cauim nas cauinagens dos Tupinambá do século XVI seria o "entusiasmo" e "leveza":

"O que faziam os participantes das cauinagens, tal como faziam os das orgias helênicas, ou das bacchanalia romanas, era atingir o enthusiasmós (...). No enthusiasmós Tupinambá buscava-se o aligeiramento, a leveza do corpo (através, por exemplo, dos vômitos, tão mal vistos pelos observadores, ou da extenuação provocada pelas danças intermináveis) e, mais do que tudo, escapar - ao menos por algumas horas - de uma humanidade que era uma condição temporal, e não uma essência, ou uma natureza". ${ }^{50}$

Mais ainda, mesmo nos casos em que os efeitos do cauim em cauinagens se expressam pela "embriaguez", como entre os Yudjá, a expressão pode ser usada para significar estados de espírito que se podem atingir igualmente de outros modos não etílicos, como por exemplo no ato de matar um inimigo: "conta-se que em uma guerra a hora exata de matar embriaga instantaneamente" ${ }^{\circ 1} \mathrm{Na}$

${ }^{48}$ Cf. JUNQUEIRA, Carmen. "Cinta-Larga". Enciclopédia dos Povos Indígenas. Instituto Socio-Ambiental. http://www.socioambiental.org/pib/epi/cintalarga/cintalarga.shtm. A referência tanto ao consumo excessivo de cerveja de mandioca como forma de o preparar renovadamente para beber é muito recorrente nas descrições das cauinagens. Jean de Léry também o refere por relação aos Tupinambá do século XVI: “Com efeito, eu os vi não só beberem três dias e três noites consecutivas, mas ainda, depois de saciados e bêbados a mais não poder, vomitarem quando tinham bebido e recomeçarem mais bem dispostos do que antes" (Léry 1972 [1578]: 91). Deste ponto de vista da provocação do vômito é de notar a excepção do caso dos Yudjá: "Diferentemente de outros grupos indígenas que fabricam cauim, os Yudjá não costumam vomitar para beber mais. O vômito não é valorizado; surge como um transtorno, geralmente atribuído ao fato de se ter comido antes de beber. Afirma-se que estômago de curimatã é um ótimo remédio contra essa náusea" (Lima 1995, Capítulo 6, nota 25).

${ }^{49}$ FAUSTO, Carlos. Inimigos Fiéis: história, guerra e xamanismo na Amazônia. São Paulo: Editora da Universidade de São Paulo, 2001, p. 423.

${ }^{50}$ FERNANDES, Selvagens Bebedeiras, op.cit., p. 327. Para além dos cronistas portugueses e franceses, também os holandeses sublinharam o fato dos Tupinambá provocarem o vômito para voltar a beber (cf. FERNANDES, op.cit., p. 354).

${ }^{51}$ LIMA, Um Peixe Olhou para Mim, op.cit., p. 253. 
verdade, seguindo o argumento de Fernandes podemos quase reverter os termos de uma teoria da aculturação. O fato dos Tupinambá de Olivença não considerarem a cerveja de mandioca como uma bebida inebriante poderia ser mais reportado para o passado do que para uma interpretação recente, já que nos mostra que o teor alcoólico de muitas das cervejas usadas atualmente na Amazônia é resultado de modificações mais recentes: "naquela região encontraremos métodos que aprofundam a manipulação humana dos microorganismos responsáveis pela fermentação",52.

\section{Sem nostalgia}

"Antigamente tinha os catutos, os cabaços assim oh [estica os braços] de vinte litros, trinta litros... Uns diziam que chegavam os parentes, né? E minha mãe enchia um caldeirão assim de giroba, botava para esquentar lá no fogo e quando estava morninho dava para todo o mundo beber" (homem Tupinambá de Olivença, com cerca de 45 anos de idade, residente no Curupitanga/Olivença)

Como referi acima, a distinção que ouvi ser feita pelos Tupinambá de Olivença entre "giroba de três dias" e "giroba de um dia" refere-se a uma correspondência entre o tempo de descanso da bebida e o nível de fermentação. Mas para além desta correlação, os adultos com mais de trinta anos de idade referem com insistência que a celeridade com que a bebida fermenta também depende do recipiente onde é deixada fermentar, já que no passado usavam certas cabaças para guardar a bebida que aceleravam o processo, de tal forma que se conseguia obter apenas num dia o mesmo nível de espuma/fermentação do que em três dias guardada num recipiente de alumínio. Os Tupinambá de Olivença conhecem esta cabaça (Cucurbitaceae, Lagenaria siceraria (Molina) Stand, n.c.) pelo nome de catuto.

O catuto foi-me descrito como uma cabaça grande e redonda, mais estreita no alto que no bojo, podendo corresponder à jamaru-cabaça $a^{53}$. Para aferir o

\footnotetext{
${ }^{52}$ FERNANDES, Selvagens Bebedeiras, op.cit., p. 82.

${ }^{53}$ CUNHA, Manuela Carneiro da e ALMEIDA, Mauro (orgs.). Enciclopédia da Floresta. O Alto Juruá: Práticas e Conhecimentos das Populações. São Paulo: Companhia das Letras, 2002, p. 639.
} 
exato tamanho desta cabaça temos apenas a referência de nela caberem cerca de 20 litros de giroba e também a descrição gestual da abertura e arqueamento dos braços que nos leva a imaginar um receptáculo com cerca de um metro de comprimento $^{54}$. As descrições feitas pelos Tupinambá sobre o uso do catuto deixam claro que para servir de recipiente para a giroba o catuto tem que ser preparado: primeiro serra-se no cimo "a boca" e depois limpa-se por dentro, deixando secar sem que apanhe sol, pois pode rachar-se. É espantosa a semelhança de termos e significados usados pelos Tupinambá, independentemente da área territorial por eles habitada, para falarem do catuto e o relacionarem com a fermentação. Uma das melhores sínteses desta relação foi-me expressa por um índio morador na Serra das Trempes "o catuto, aquelas cabaçonas, ali já era praticamente a giroba". "Ser a giroba" quer aqui dizer que já era bebida fermentada. De fato, voltando a prestar atenção ao processo de preparação desta bebida, verificamos que o tempo de fermentação estimado pelos índios é bem mais reduzido se for usado o catuto e que este processo de fermentação é induzido a partir da produção de espuma.

"- Qual era o sabor que dava o catuto?

- Ah, é porque avinha, fica avinhada, a mandioca. Machuca ela, abafa na peneira e bota dentro do catuto e ele vai fervendo, ele próprio dá .. uma panela mesmo, fica azedo, aquela espuma em cima." (mulher com cerca de 70 anos de idade, residente no Cururutinga)

Para além do catuto e das panelas de alumínio os Tupinambá também referem a utilização de "panelas de barro" ou "potes de barro" para fermentar a giroba, mas para diferentes mulheres e homens com quem falei sobre o assunto é certo que no catuto o processo de fermentação era ainda mais célere do que no barro.

Segundo acabei por concluir ao fim de várias inquirições, o catuto não é utilizado pelos Tupinambá de Olivença há cerca de vinte a trinta anos. Alguns atribuem este desaparecimento ao fato de não se ter mais visto a semente, enquanto outros simplesmente não o encontram no mato, porque nem todos os

\footnotetext{
${ }^{54} \mathrm{O}$ wikdicionário remete o termo "catuto" para um brasileirismo usado em Santa Catarina para uma cabaça "Fruto grande em forma de pêra usado como bóia em pescaria. Quando cortado ao meio é usado como utensílio doméstico ou para tirar água nos pequenos barcos." (http://pt.wiktionary.org/wiki/catuto).
} 
Tupinambá pensam no catuto como uma cabaça de cultivo. Não há dúvida quanto ao entusiasmo dos Tupinambá ao falarem do catuto, desses "grandes catutos", mas não há qualquer sentido de nostalgia que provoque vontade de recuperar as sementes ou cultivar os catutos. Atualmente nem mesmo os potes de barro são comuns. A inacessibilidade a áreas de rio com lama suficientemente boa para fazer barro é em muitos casos a justificação para o uso mais comum de panelas de alumínio. Mas a referência aos catutos é descomprometida, não explora sentimentos de perda que suscitem recuperação. Se podíamos ver aqui um potencial para a re-tradicionalização é no entanto sem nostalgia que os Tupinambá de Olivença se referem aos catutos, ainda que seja fácil de imaginar, no entanto, que se eles voltassem a aparecer seriam reintegrados com imediato pragmatismo.

\section{Prazer}

- Como é que fazia? - Fazendo. A gente gostava. - Seus pais faziam também.. - Fazia. - E você bebia quando era pequeno?

- Bebia. ..(hã. hã....) - Dava para os meninos porquê? - Porque eles gostavam também, né? - E fazia como? - Botava no pilão e no ralo e bebia. Negócio de índio. (Homem de setenta anos, habitante no Cururutinga)

$\mathrm{O}$ alto rendimento social das práticas alimentares tem sido largamente observado pelos antropólogos que trabalham com os ameríndios contemporâneos. Uma das dimensões mais relevantes nestas práticas é a expressão de uma preferência gustativa que associa a constituição da pessoa ao gosto por certo tipo de comidas. Se Viveiros de Castro sublinha o teor filosófico que as práticas alimentares podem ganhar na vida ameríndia, ao refletir sobre o canibalismo Wari', Peter Gow e Joanna Overing têm mesmo discutido a importância do prazer como dimensão ética, isto é, constitutiva da moralidade, de disposições de ação social e de constituição da identidade e diferença ${ }^{55}$. No caso da giroba,

\footnotetext{
${ }^{55}$ VIVEIROS DE CASTRO, "Apresentação", op. cit.; GOW, "The Perverse Childe", op. cit.; OVERING, Joanna e PASSES, Alan. "Introduction”. In The Anthropology of Love and Anger: the esthetics of conviaviality in Native Amazonia. Londres: Routledge, 2000, pp. 1-30.
} 
aquilo que começa por se destacar é a preferência por uma bebida por definição azeda num contexto regional como a Bahia contemporânea, onde as práticas gustativas são comandadas por um intenso adocicado.

Nem todos os Tupinambá de Olivença gostam de beber giroba e claro que há muitas variações gustativas que corresponderão à mesma variabilidade pessoal que atribuímos às personalidades individuais. Mas num contexto como a Bahia em que toda a comida é altamente açucarada torna-se mais evidente e fácil de reconhecer a necessidade de uma explicação social, cultural e histórica para o fato de encontramos tantos homens, mulheres e crianças Tupinambá de Olivença com desejo e manifestação de prazer na ingestão de uma bebida azeda e morna ${ }^{56}$.

Ainda que se comente que as crianças Tupinambá de Olivença não gostam de beber giroba, explicando-se assim a razão pela qual se chega a administrar a bebida quando elas estão a dormir, também pude verificar que em muitos casos acontecia o reverso. Algumas crianças, nascidas e criadas em áreas residenciais indígenas onde os alimentos processados de mandioca são abundantes e ingeridos quotidianamente, manifestam claro prazer por beber giroba, ficando felizes quando sabem que vai ser preparada e implorando que lhes seja dado a beber, como pude observar ser o caso durante o primeiro período de trabalho de campo.

Certa manhã, em 1998, em Sapucaeira, uma senhora idosa que residia na mesma unidade compósita de residência trouxe um recipiente com giroba. Vinha oferecê-la à mulher principal da casa, ela mesma idosa. Ao formular a sua intenção, um menino de quatro anos, neto desta senhora e seu filho de criação implorou por um copo de giroba. Como se não lho dessem com a rapidez esperada (para uma criança desta idade exigir comida é atendido com prontidão), começou a chorar, insistindo na sua vontade pela giroba. Acabaram por lha dar mais rapidamente do que à sua avó, evitando continuar a ouvir a súplica. Mal o teve na mão, correu para um canto (como se faz com um alimento que se quer tanto que se teme perdê-lo só com o olhar dos outros), e bebeu-a tranqüilamente. Essa é a forma de beber giroba: bebe-se sempre devagar, o que ajuda a que não haja atrapalhação com os grumos e a espessura do líquido quando ela não é "coada".

Os Tupinambá adultos que lembram normalmente com desagrado o sabor da giroba que bebiam quando eram crianças são aqueles que há mais tempo

\footnotetext{
${ }^{56}$ Vi diversas vezes os Tupinambá residentes na vila refrigerarem a giroba nas suas geladeiras para darem a beber a convidados menos acostumados com este tipo de paladares.
} 
abandonaram a vida em áreas onde a mandioca cresce: aqueles que vivem uma vida urbana de forma mais identificadora, na qual os hábitos alimentares deixam de se relacionar com este tipo de derivados da mandioca ou "terra da mandioca". Fui conhecendo vários casos. Por exemplo, jovens adultos que saíram de Olivença desde a adolescência, indo viver uma vida urbana em Ilhéus ou Salvador.

Mas num sentido quase inverso verificamos a enorme importância da giroba para a identificação de homens e mulheres como Tupinambá, bem como para o relacionamento entre casais, mesmo aqueles que vivem nos extremos do território de Olivença, afastados das localidades onde existe maior concentração demográfica de índios. É normalmente um pai ou esposo a solicitar a uma filha ou esposa que lhe prepare giroba. Reparei que o termo usado chega a ser o de "mandar" fazer giroba: "Era ela que fazia, né? Ele mandava. Ela fazia e tudo bebia". No caso do casal de um marido índio e esposa não-índia esta envolve-se no processo tendo que aprender como preparar cerveja com um qualquer elemento da família do marido.

A vida de um dos casais que conheci e morava na área de montanhas que encerram o horizonte territorial habitado pelos Tupinambá de Olivença é exemplar a este respeito. Quando conheci este casal estavam ambos em casa, junto com um filho adolescente que mais tarde compreendi ser um filho de criação. $\mathrm{O}$ homem (pai deste adolescente) tem por volta de sessenta anos de idade e ela cinquienta. Ele já é filho de um não-índio com uma índia que o pai trouxera consigo para a área das serras quando se casaram. Nasceu ali e acabou também por casar com uma mulher que não é índia. Na nossa conversa explicou-me que quando era pequeno a mãe fazia-lhe giroba e cresceu a gostar tanto que de tempos a tempos pede à esposa para lha preparar. A esposa aprendeu com a sogra (a mãe índia do marido) por ter vontade de responder à solicitação do marido.

A descrição do dia em que ela aprendeu com a sogra é significativa a diversos níveis. Primeiro, viu a sogra fazer - explicou - e ouviu as suas recomendações. Disse-lhe, por exemplo, que "com três dias" (a azedar) estava boa para beber. Mas da primeira vez que ela mesma experimentou fazer para o marido achou que fermentando um só dia já estaria pronta, sendo exagero da sogra deixá-la três dias à espera. A partir dessa altura, sempre que prepara giroba faz num dia e dá a beber ao marido no dia seguinte. Na altura em que aprendeu com a sogra, esta deu-lhe um pouco de giroba a provar. Ela bebeu (confessa agora) apenas porque não fazia idéia do sabor que tinha. Achou de imediato "ruim" e rejeitou-a instintivamente, como explicou: "eu botava na boca e 
deitava fora". Ao longo dos anos de casada foi-se "acostumando", mas mesmo assim, diz: "não sou bem chegada, não".

Apesar desta rejeição corporal que sentiu à giroba, foi dando aos filhos quando eram crianças, por ouvir dizer ser boa para a saúde. Garantiu ainda que eles a "tomavam" com alguma facilidade. Ao dizer isto, porém, o filho presente não se conteve, acrescentando que "tomava e tomo, mas não sou chegado não. Antigamente eu tomava... E tomo, mas não sou chegado. Se for bem coado é melhor. Não sou chegado não. Quem gosta mesmo é pai”. O rapaz há vários anos que estuda em Buerarema - uma cidade próxima desta área - e mais tarde confessou-nos que não gosta mesmo de beber giroba. De fato, beber giroba na infância não significa necessariamente que se fique a gostar ou a ter prazer em bebê-la pela vida fora. "Tudo com açúcar é bom" - argumentava ainda este jovem rapaz para explicar porque é que mesmo assim acabava sempre por beber um copo para acompanhar o pai.

O consumo da giroba implica o prazer de a beber, de pedir a uma esposa que aprenda a fazer ou a uma filha para a $\operatorname{preparar}^{57}$. O riso e boa disposição que as conversas sobre a giroba suscitam nos meus interlocutores, quer vivam na zona da costa quer na das montanhas são indicativos dos sentidos afetivos e emotivos que a bebida lhes suscita. Se é verdade que a cachaça também é

\footnotetext{
${ }^{57}$ A preparação e consumo de bebidas fermentadas e até de muitos outros derivados culinários da mandioca entre os povos sul-ameríndios tem sido sistematicamente relacionada com questões de gênero, salientando-se, principalmente, as formas de reciprocidade entre marido e esposa. Cf. GOW, "The Perverse Child”, p. 570; GUZMÁN, Para que la yuca beba nuestra sangre, op.cit.; (cf. Gow 1989: 570, 1991, Guzman 1997, UZENDOSKI, "Manioc Beer and Meat", op.cit., p. 888; LIMA, Um Peixe Olhou para Mim, op.cit., pp. 288-289). Um outro debate paralelo tem vindo a relacionar esta questão com o poder de gênero, encetado pela controversa tese de Peter Rivière de que a sofisticação e complexidade na preparação de derivados da mandioca seria tanto maior entre povos sul-ameríndios quanto fosse preciso ao homem controlar a sua esposa - como aconteceria exemplarmente em situações de virilocalidade. RIVIÈRE, Peter. Peter. Individual and Society in Guiana: a comparative study of Amerindian social organization. Cambridge: Cambridge University Press, 1984, p. 92. Para o debate e refutação desta tese vejase McCALLUM, Cecilia. Gender and Sociality in Amazonia. How Real People are Made. Oxford: Berg, 2001; GUZMÁN, Para que la yuca, op.cit.; BELAÚNDE, Viviendo bién, op.cit., pp. 179-180); e BELAÚNDE, Luisa Elvira. El recuerdo de Luna: género, sangre y memoria entre los pueblos amazónicos. Lima: Fondo Editorial de la Facultad de Ciencias Sociales, 2005, pp. 92-94. Entre os Tupi Yudjá, por exemplo, a questão do poder coloca-se de forma bem mais complexa, já que os maridos pedem à esposa que faça cauim com o qual irão simbolicamente matá-los (cf. LIMA, Um Peixe Olhou para Mim, op.cit.).
} 
desejada, a giroba convoca um tipo de desejo envolvente de pessoas e memórias afetivas. Bebe-se tranqüilamente não apenas pelos grumos e espessura grossa, mas também porque o ato de beber constitui em si um momento de prazer. A convivialidade suscitada pela giroba vai a par dos sabores que ela pode invocar. Como vimos ao longo das referências aqui feitas, a rememoração dos momentos em que se faz giroba vêm sempre acompanhados da memória de uma convivialidade onde os excessos limpam o corpo ao invés de o impelir a comportamentos ambivalentes, como acontece nos serões ou festas acompanhados de cachaça. É então esse prazer pela bebida que argumento ser central na persistência da giroba como identificação dos Tupinambá de Olivença.

De fato, para os Tupinambá de Olivença a mediação da alimentação pode mesmo ancorar um sentimento de atração romântica. Uma mulher com os seus cinqüenta anos, não-índia, expressou-me certa vez os sentimentos de atração do seu marido Tupinambá de Olivença dessa forma. O namoro aconteceu no período em que ela vivia numa cidade a cerca de $50 \mathrm{~km}$ de Sapucaeira e só voltava a casa dos pais uma vez por mês. $\mathrm{O}$ seu atual marido começou a reparar nela sem que fosse capaz, contudo, de expressar esse sentimento. Na perspectiva dela "esse pessoal [índio] é todo acanhado. Para conversar alguma coisa...". Ela sabe que na época enchia os olhos dos rapazes, "toda bonitona", e ele "ficava doido", querendo falar com ela. Certo dia recebeu um bilhete dele. Soube que ele o tinha ditado à irmã expressando os seus sentimentos nesta curta frase: "você quer vir queimar o meu feijão?".

A intermediação do alimento na relação entre marido e esposa passa largamente, portanto, pelo afeto envolvido na solicitação para se preparar um alimento. Como nos alerta Peter Gow, no caso sul-ameríndio há que ser mais generoso com as possíveis implicações de relações intermediadas por certos alimentos: "Nas culturas nativas da Amazônia o corpo e os seus desejos são de enorme significado social e a satisfação do desejo corporal é simultâneo à criação de relações sociais" "58.

No caso da ingestão de giroba pelos Tupinambá de Olivença é fundamental que tenhamos em conta a relação entre essa dimensão sensível e gustativa, a sua inscrição ontogênica na formação de "caboclos fortes" e o fato de se tratar de uma bebida preparada com mandioca. Aqueles que por muito tempo abando-

${ }^{58}$ GOW, "The Perverse Child", p. 581. 
nam esta "terra da mandioca" têm maior dificuldade em voltar a beber uma bebida que os hábitos alimentares adocicados da Bahia tornarão excessivamente exótica. Entre casais "mistos" que habitam em localidades com poucos índios e portanto mais afastados, a diversos níveis, do convívio e modo de vida dos Tupinambá de Olivença, como é o caso das regiões da serra que confinam o território, a ligação à giroba tende a ser um elo na memória afetiva de identificação como Tupinambá.

\section{Nojo}

"No que nos diz respeito, ao chegarmos a êsse país procuramos evitar a mastigação no preparo do cauim e fazê-lo de modo mais limpo" (Léry 1972 [1578], p. 93).

Segundo nos é possível determinar, a partir da idade e memória dos Tupinambá adultos, no final do século XIX os Tupinambá de Olivença acrescentavam ao processo de preparação da giroba a "mastigação" ou "salivação", associada à fermentação ${ }^{59}$. Não conheci ninguém que tivesse vivido no período em que esse procedimento era comum, mas na medida em que ele é reportado como uma prática que os pais dos mais idosos ainda presenciaram podemos mesmo supor que no início do século XX os Tupinambá de Olivença salivassem a giroba. Conheci mulheres e homens entre os cinqüenta e os setenta anos de idade que me asseguraram que a prática era ainda comum entre os avós e que os pais ainda teriam presenciado esse procedimento quando eram crianças. Esta proximidade histórica não deixa de ser notável, já que desde Jean de Léry que se ouvem diretivas coloniais no sentido de acabar com o "mau-costume", como na citação em epígrafe desta seção.

Importa principalmente entender os sentimentos dos Tupinambá de Olivença em relação a essa prática do seu passado e também o sentido que lhe conferem. Ao mesmo tempo que tantas vezes me deparei com as gargalhadas

\footnotetext{
${ }^{59}$ De fato, como explica sucintamente Fernandes: “Ao mascar amiláceos como a mandioca ou o milho, as índias no Brasil nada mais faziam, ou fazem, do que atrair as leveduras úteis e colocá-las a seu serviço" (FERNANDES, Selvagens Bebedeiras, op.cit., p. 53). É a enzima existente na saliva que permite converter uma parte do amido nos açúcares de que se alimentam os fermentos (ERIKSON, "L'art de couler", op.cit., p. 249).
} 
instantâneas mal mencionava o assunto da giroba, não deixei de notar a mudança de humor provocada pela referência à mastigação. A seriedade é normalmente um prelúdio à afirmativa de que essa prática só era possível quando os índios tinham "os dentes sãos". "Só mastigava quem tinha os dentes perfeitos" e essas mulheres do passado eram "índias de dentes muito sãos" diferentes de si-próprias "que nós tínhamos o dente estragado".

Diversas mulheres e homens de meia-idade souberam descrever como as mulheres se juntavam para mastigar a mandioca, sendo as "moças" (ou seja as mulheres solteiras) quem mais comumente o fazia, preparando-se num "resguardo". Mas tanto a seriedade com que se refere o fato como a constante menção aos “dentes sãos" das moças não são indicativas de nostalgia pelo passado. Muito pelo contrário, neste caso trata-se exatamente do oposto. Para os Tupinambá de Olivença uma das formas de se explicar o que de positivo existe em não serem índios "selvagens" "das aldeias" é muitas vezes remetido para um maior entendimento do mundo dos brancos que lhes é favorável: hoje são "mais sabidos". Assim por exemplo se repete que se eles perderam as suas terras é porque "antigamente eram tolos", "não sabiam de nada". Em alguns casos os próprios Tupinambá de Olivença referem esta diferença entre o que são hoje e o que eram no passado, identificando-se agora como "índios civilizados". Para muitos a razão pela qual não se mastiga a mandioca no processamento atual da giroba é porque "hoje o pessoal está muito civilizado. Mais do que naquele tempo". Não mastigar a mandioca é visto como uma ruptura positiva com o passado, que não se quer reverter. Parte do que é também positivo nesta situação de índios "civilizados" é o relacionamento com os brancos e a relação entre um assunto e o outro aparece com alguma freqüência ${ }^{60}$ :

\footnotetext{
${ }^{60}$ Vale a pena referir que os cronistas dos Tupinambá do século XVI e XVII tanto mencionavam ter experimentado a bebida e ela ser agradável, associando mais a sua repulsa ao fato de saberem que na sua preparação se juntava saliva das índias do que ao seu sabor. No entanto, Montaigne diz que é "ácida" e Jean de Léry refere que "tem como que o gosto de leite azêdo" (LÉRY, Viagem à Terra do Brasil, op.cit., p. 90). Tanto o valor medicinal para o estômago como o exotismo do sabor da giroba estão curiosamente presentes na seguinte passagem de Montaigne: "Essa beberagem só se conserva por dois ou três dias; tem o gosto um pouco picante, não exala vapores, é salutar para o estômago e laxativa para os que não estão acostumados; é uma bebida muito agradável para quem está habituado a ela" (MONTAIGNE, "Dos Canibais", op.cit., p. 310). Numa nota de Sérgio Milliet à edição aqui consultada do livro de Jean de Léry o tradutor cita o mesmo texto de Montaigne com algumas pequenas diferenças que vale a pena mencionar. Assim, em vez de "um pouco picante" traduz "é um pouco ácida" e em vez de "exala vapores" traduz "não embriaga" (citado in LÉRY, Viagem à Terra do Brasil, op.cit., p. 90).
} 
"O povo antigamente é que criou essas divisões. Que havia madeira para fazer machucador e a giroba era amachucada no pilão. Mas o povo criticava... os não-índios principalmente, que o índio mastigava no dente e jogava novamente; criaram um meio de menosprezar o índio. O povo dizia que o índios mastigava e depois colocava na mesma vasilha" (Mulher com 74 anos, Campo de São Pedro).

Uma outra mulher da região do Acuípe com cerca de sessenta anos de idade encerrou de forma veemente a conversa que estávamos a ter sobre o assunto lembrando-me que uma das razões pelas quais se salivava a giroba no passado era também por não se partilhar a bebida com "gente de fora", ao que acrescenta: "como você". Há assim a idéia de que o fim da prática de salivação corresponde a um processo de maior alargamento da convivialidade para a relação com outros, cuja relação não pode integrar a comensalidade, a mesma substância, o mesmo corpo. Não se pode partilhar comida, em suma, com um outro, potencial inimigo, pois desse se deve esperar mais desconfiança do que partilha.

A significação desta estranheza e desconfiança foi-me sugerida através de uma conversa com uma mulher de Sapucaeira, com filhos e netos, que me conhecia de há já longo tempo e expressou este corte com o passado introduzindo a questão do nojo. Referia a idéia a partir do que ela própria se lembra ainda de ter sentido em criança, quando recusava beber giroba em casa de qualquer outra pessoa senão a sua mãe. $O$ "nojo" classifica a ingestão de um alimento que foi salivado por alguém com quem eu não tinha previamente um laço social:

Sap: Meu pai falava que antigamente era assim mesmo. Ele falava assim que escolhia aquelas moças de dentadura boa, que não tinha nenhum dente estragado.

Ant: Eles falavam porque faziam isso?

Sap: Não falou não. Eles falavam e eu achava que isso era uma nojeira. Eu mesmo não bebia giroba na casa de ninguém. Eu bebia só a que a minha mãe fazia, mas na casa dos outros assim... Ainda mais ele contando isso...

E aí você acha que é o quê? Eu, que eu não sei de nada, eu acho que isso é uma nojeira. E você acha que é o quê?"

Ela presumia que tivéssemos a mesma opinião sobre o assunto e na ocasião concordei com ela. Contudo, o que ela aqui expressava como "nojeira" não era o que eu significaria nem a higienização a que se referia Jean de Léry na 
epígrafe a esta seção, quando menciona a necessidade de utilizar um "método mais limpo" para fazer cauim $^{61}$. Algumas das teorias cognitivas sobre o sentimento de nojo (disgust) consideram que ele surge primordialmente através de experiências relacionadas com o paladar e que o protótipo para a expressão do nojo se encontra ligado a uma repulsa física de certos alimentos manifestada como uma "rejeição ideacional" 62 . Por outras palavras, o nojo manifesta-se pela imaginação do que estará por trás daquele alimento, mais do que por um desagrado de paladar. $\mathrm{O}$ alimento não é independente de quem o preparou e esta idéia é muito útil para compreender os sentidos implicados na desconfiança de se comer algo preparado por outrem, como se repercute na dificuldade de muitos ameríndios em aceitar comida preparada por alguém com quem não tenham previamente laços sociais, como é descrito por exemplo por Dominique Gallois e Vincent Carelli a propósito da dieta dos Wayãpi quando visitaram pela primeira vez os Zoé ${ }^{63}$. A tendência de muitos povos sul-ameríndios para abandonar o processo de salivação pode então explicar-se, como tem sido feito, como parte de uma "estratégia de identidade" dos povos indígenas para ganharem respeito político, mas a mudança do método não corresponde a uma higienização ${ }^{64}$. Para os Tupinambá de Olivença o corte radical com a salivação

\footnotetext{
${ }^{61}$ Não deixa de ser espantosa a facilidade com que Jean de Léry relativiza esta atitude de nojo face à mastigação da mandioca para fermentação lembrando "o modo pelo qual entre nós se fabrica o vinho. (...) Os lindos pés, às vezes calçados de sapatões, machucam as uvas” e por isso concluímos que "nesse mister [do vinho] se passam muitas coisas talvez menos aprazíveis do que a mastigação das mulheres americanas". LÉRY, Viagem à Terra do Brasil, op. cit., p. 94.

${ }^{62}$ ROZIN, Paul, HAIDT, Jonathan, McCAULEY. "Disgust”, Handbook of Emotions. Nova York: Guilford Press, 1993, pp. 579, 590.

${ }^{63}$ GALLOIS, Dominique T. e CARELLI, Vincent. "Diálogo entre Povos Indígenas: a experiência de dois encontros mediados pelo vídeo". Revista de Antropologia 38 (1), 1995, pp. 205-259.

${ }^{64}$ Cf. ERIKSON, “L'art de couler", op.cit., p. 249. Deste ponto de vista do uso das bebidas fermentadas em processos políticos de identidade havia ainda que considerar a situação numa análise comparativa mais microscópica tanto entre povos indígenas como entre colonizadores. De fato, como mostra João Azevedo Fernandes "Do choque de culturas e etnias que deu origem à sociedade brasileira emergiu um regime etílico que se construiu, em sua parcela mais importante, em torno de uma bebida destilada, e não das velhas bebidas fermentadas nativas, ao contrário do que ocorreu em outras áreas de colonização européia - como o Peru e o México - onde bebidas como a chicha e o pulque mantiveram um lugar importante nas culturas e sociedades resultantes do contato" (FERNANDES, Selvagens Bebedeiras, op.cit., pp. 312-313). Esta diferença em relação ao Peru e ao México é fundamental para avaliar o próprio papel atual das bebidas fermentadas em processos de identidade politizada.
} 
só pode ser inteiramente compreendido pela sua paralela sobreposição entre socialidade, substância e alimentação.

\section{Conclusão}

Neste artigo comer fermentado constituiu-se como objeto de análise das combinações entre sociedade e cultura entre os Tupinambá de Olivença, mais uma vez sublinhando uma das idéias teóricas mais centrais na compreensão das socialidades ameríndias, a saber, que "os discursos indígenas sobre a corporalidade e a pessoa" são "informadores da praxis social concreta e única via não etnocêntrica de inteligibilidade desta praxis" ${ }^{65}$.

Construir pessoas, fabricar corpos e até fazer parte do que teríamos que chamar "um povo" passa assim por se sentir prazer e desejo em beber giroba, no âmbito de um complexo campo de socialidades onde cozinhar para outrem é constitutivo de amor, dar de comer a uma criança é constitutivo de maternidade e por aí fora. $\mathrm{O}$ desejo e a moral estão aqui entrelaçados, como verificamos nas relações mútuas entre marido e esposa ou entre pai e filha, desencadeadas pela solicitação e preparação da bebida. Se muitos dos vizinhos não-índios dos Tupinambá de Olivença também sabem fazer giroba e podem até ter prazer em bebê-la, os homens não-indígenas não pedem às suas esposas que aprendam a fazer ou elas não são por iniciativa própria levadas a aprender para agradar o seu marido. Principalmente, estas esposas não se dedicam a preparar giroba e a dá-la aos seus filhos se não tiverem por trás a convicção cultural historicamente perpetuada e socialmente sustentada de que aquela bebida os faz crescer com corpos mais fortes e de caboclo.

A moralidade e o desejo aparecem aqui, portanto, entrelaçadas, no mesmo sentido com que Joanna Overing se tem referido a uma "estética da moralidade amazônica que também se centra na intenção e no desejo", sendo que a ligação

Se no México ou no Peru estas podem ser imediatamente reconhecidas como elementos tradicionais e ao mesmo tempo entraram nos hábitos alargados de ingestão alimentar, no caso do Brasil uma possível mercantilização da giroba como bebida indígena não vingaria da mesma forma. Cf. VIEGAS, Susana de Matos. "Depois da Diferença: Identificações étnicas e de classe num contexto indígena no sul da Bahia". In SANTOS, Boaventura de Sousa; COHN, Amélia e CAMARGO, Aspásia (orgs.). O Diálogo dos 500 anos: Brasil-Portugal entre o passado e o futuro. Rio e Janeiro: EMC Edições, 2000, pp.261-283.

${ }^{65}$ SEEGER, MATA e VIVEIROS DE CASTRO, "A Construção da Pessoa", op.cit., p. 16. 
entre desejo/intenção e moralidade "é contrário à filosofia moral contemporânea que, desde Kant, purifica a ética de toda a estética e desejo" ${ }^{\text {"66 }}$. A importância do reconhecimento desta dimensão da socialidade está em sermos capazes de compreender, então, como é que os Tupinambá de Olivença que vivem há várias décadas numa mesma área regional, mas há muito não se juntavam por razão alguma para fins coletivos, partilham sentidos e formas de estar-no-mundo. Aqui mostramos como esta partilha se explica do ponto de vista socioeconômico pela sua vivência numa "terra de mandioca".

Do ponto de vista da existência desta socialidade numa perspectiva de longaduração, para fins conclusivos recorro a uma orientação teórica desenvolvida por João de Pina-Cabral para um contexto bem afastado dos povos sul-ameríndios: a análise das tendências de longa-duração nas relações de parentesco na China. Ao tratar da forma como as mulheres macaenses com um padrão de vida moderno vão perpetuando sentidos do parentesco chinês, João de Pina-Cabral argumenta que estas lógicas fortes de continuidade dizem respeito à "base emocional de integração social das pessoas" que no caso macaense se prendem por exemplo com a idéia da reprodução familiar assentar na relação entre homens e não no casal ou princípio de stabilitas que funda historicamente as relações familiares na Europa. Assim, por exemplo, mostra-nos como apesar das mulheres em Macau terem deixado de residir virilocalmente (na mesma casa dos sogros) e da patrilinearidade não se verificar nem formalmente nem na prática, o casamento continua a envolver uma compensação da parte dos pais do noivo pelo gasto que tiveram na criação daquela mulher que agora entregam a outrem ${ }^{67}$. Assim conclui o seguinte sobre esta perspectiva histórica:

Hoje, como no passado, os protótipos essenciais que estruturam as compreensões espontâneas das pessoas sobre relações familiares em Macau não se focalizam na imagem Européia e Ocidental (supostamente moderna e biológica) do casal conjugal com o seu filho (a cena da natividade cristã como protótipo de uma espécie de "família natural"). Este facto tem profundas implicações para os sentimentos das pessoas sobre justiça". ${ }^{68}$



${ }^{67}$ PINA-CABRAL, Between China and Europe, op.cit., pp. 182-185.

${ }^{68}$ PINA-CABRAL, Between China and Europe, op.cit., p. 190.
} 
Transposto para a situação e contexto aqui em análise podemos então dizer que ao tratarmos da forma como o corpo de um Tupinambá se constitui pelo desejo de comer fermentado e pela socialidade envolvida nele estivemos a lidar com bases emocionais de integração social das pessoas. Prazer e persistência, no entanto, vão se articulando com rejeição e anulação de certos hábitos do passado, neste sentido integrando uma visão do tempo histórico que melhor poderíamos aproximar a um complexo de "transformações indígenas" no sentido que tem sido dado à expressão por Peter Gow. Uma das implicações da visão da história indígena como um "sistema de transformações" é que ela exclui definitivamente a idéia de uma reflexão sobre o passado a partir de um referente a "um tempo, uma estrutura cultural ou sociedade (...) estável, direcionada para uma reprodução auto-referencial que se começou a transformar apenas devido a interferências externas" ${ }^{\text {69 }}$. Estas transformações estiveram presentes no confronto entre o uso de cerveja fermentada para fins festivos e o seu uso "doméstico", repensando-o à luz de uma contraposição entre beber fermentado na constituição de socialidades seculares e beber destilado em sociabilidades festivas. $\mathrm{O}$ exagero manifesta-se de forma diferente: no fermentado - o transbordo do corpo que enche até verter para fora com o vomito - e no destilado - a euforia, o soltar da fala normalmente "cismada", os abraços ostensivos e a convivialidade verdadeiramente extravasante. Do conhecimento disponível sobre o que era o fermentado para os Tupinambá dos séculos XVI e XVII dificilmente podemos julgar se o valor nutritivo do cauim, normalmente obscurecido nas descrições das cauinagens, não teria um peso tão profundo como o sentido ontogênico que hoje podemos reconhecer na giroba para os Tupinambá de Olivença.

\footnotetext{
${ }^{69}$ GOW, Peter. An Amazonian Myth and its History. Oxford: Oxford University Press, 2001, p. 286.
} 